\title{
Thalassemys bruntrutana n. sp., a new coastal marine turtle from the Late Jurassic of Porrentruy (Switzerland), and the paleobiogeography of the Thalassemydidae
}

Christian Püntener, Jérémy Anquetin, Jean-Paul Billon-Bruyat

Background. The Swiss Jura Mountains are a key region for Late Jurassic eucryptodiran turtles. Already in the mid 19th century, the Solothurn Turtle Limestone (Solothurn, NW Switzerland) yielded a great amount of Kimmeridgian turtles that are traditionally referred to Plesiochelyidae, Thalassemydidae, and Eurysternidae. In the past few years, fossils of these coastal marine turtles were also abundantly discovered in the Kimmeridgian of the Porrentruy region (NW Switzerland). These findings include numerous sub-complete shells, out of which we present two new specimens of Thalassemys (Thalassemydidae) in this study. Methods. We compare the new material from Porrentruy to the type species Th. hugii, which is based on a well preserved specimen from the Solothurn Turtle Limestone (Solothurn, Switzerland). In order to improve our understanding of the paleogeographic distribution of Thalassemys, anatomical comparisons are extended to Thalassemys remains from other European countries, notably Germany and England.Results. While one of the two Thalassemys specimens from Porrentruy can be attributed to Th. hugii, the other specimen represents a new species, Th. bruntrutana n. sp. It differs from Th. hugii by several features: more elongated nuchal that strongly thickens anterolaterally; wider vertebral scales; proportionally longer plastron; broader and less inclined xiphiplastron; wider angle between scapular process and acromion process. Our results show that $T h$. hugii and Th. bruntrutana also occur simultaneously in the Kimmeridgian of Solothurn as well as in the Kimmeridgian of England (Kimmeridge Clay). This study is an important step towards a better understanding of the paleobiogeographic distribution of Late Jurassic turtles in Europe. 
1 Christian Püntener*, Jérémy Anquetin, Jean-Paul Billon-Bruyat

2 Section d'archéologie et paléontologie, Office de la culture, République et Canton du Jura,

3 Porrentruy, Switzerland

4

5 *Corresponding author:

6 Office Cantonal de la Culture, Paléontologie A16, Rue de la Chaumont 13, 2900 Porrentruy

$7 \quad+41324208463$

8 christian.puntener@jura.ch 


\section{INTRODUCTION}

Thalassemys Rütimeyer, 1873 is a coastal marine turtle from the Late Jurassic of Western

Europe (Bräm, 1965; Lapparent de Broin, 2001). It is the only currently recognized

representative of the family Thalassemydidae Zittel, 1889, a group that is potentially related to the Plesiochelyidae Baur, 1888 and the Eurysternidae Dollo, 1886 (Joyce, 2007). However, the exact relationships and systematics of these three groups are rather confused (e.g., Broin, 1994; Lapparent de Broin, Lange-Badré \& Dutrieux, 1996; Joyce, 2003; Joyce, 2007; Anquetin \& Joyce, 2014).

Rütimeyer (1859a; 1859b) first mentioned the name Thalassemys during a conference of the Schweizerische Naturforschende Gesellschaft at the University of Bern (Maack, 1869), but the name only became available in 1873 when he described and figured two species of Thalassemys from the Kimmeridgian of Solothurn, Canton of Solothurn, Switzerland: Th. hugii Rütimeyer, 1873 and Th. gresslyi Rütimeyer, 1873. The type species Th. hugii is based on a relatively flat shell with associated postcranial remains (NMS 8595-8609; formerly NMS 1), which is the largest turtle in Solothurn (preserved carapace length of $630 \mathrm{~mm}$ ). Since Rütimeyer (1873), the fossil turtles of the so-called Solothurn Turtle Limestone have undergone two major revisions (Bräm, 1965; Anquetin, Püntener \& Billon-Bruyat, 2014), both with important impacts on the taxonomy of Thalassemys. Bräm (1965) synonymized Th. gresslyi with Th. hugii and erected a new species, Th. moseri Bräm, 1965. Revealing the presence of lateral plastral fontanelles in

Thalassemys, Anquetin, Püntener \& Billon-Bruyat (2014) synonymized Eurysternum ignoratum Bräm, 1965 with Th. hugii and excluded 'Th.' moseri from Thalassemys. 
32 2014; Pérez-García, 2015), but all authors agree that this taxon should be excluded from

33 Thalassemys. This species was described by Bräm (1965) based on two shells from the

34 Kimmeridgian of Solothurn, Switzerland. A specimen from the Tithonian of western France

35 consisting of an association between a skull and a partial shell was later referred to this taxon

36 (Rieppel, 1980). Without revising the material, Lapparent de Broin, Lange-Badré \& Dutrieux

37 (1996) stated that 'Th.' moseri was invalid since they referred the two specimens from Solothurn

38 (type material) to juvenile forms of Plesiochelys solodurensis Rütimeyer, 1873, a plesiochelyid

39 from the same locality. However, they considered the material described by Rieppel (1980) as a

40 distinct and indeterminate species of Plesiochelys Rütimeyer, 1873. In 2014, Anquetin, Püntener

41 \& Billon-Bruyat (2014) revised the type material from Solothurn and concluded that 'Th.' moseri

42 was indeed a valid taxon, distinct from Plesiochelys solodurensis. In the meantime, Pérez-García

43 (2015) built upon the conclusions of Lapparent de Broin, Lange-Badré \& Dutrieux (1996) and

44 referred the material described by Rieppel (1980) to a new taxon, Jurassichelon oleronensis,

45 without reassessing the validity of 'Th.' moseri. It should be noted that the latter author failed to

46 see both the material from Solothurn and the specimen described by Rieppel (1980). Sorting out

47 this situation would require a complete revision of the material, something that has not been done

48 since 1980. It should notably be determined whether the material described by Rieppel (1980)

49 and the material from Solothurn belong to the same species. This revision is ongoing, and the

50 present paper on Thalassemys is certainly not the place to discuss further the systematics of this

51 unrelated taxon.

52 Several other species have been attributed to Thalassemys in the late 18th and early 19th

53 centuries, including Thalassemys marina Fraas, 1903 (Tithonian of Schnaitheim, Baden-

54 Württemberg, Germany), Thalassemys heusseri Oertel, 1924 (Tithonian of Holzen im Hils, 
55 Lower Saxony, Germany), and Thalassemys ruetimeyeri Lydekker, 1889 (Berriasian of Dorset,

56 England). Because the type material is lost and the original description is insufficient, $T h$.

57 heusseri must be considered a nomen dubium. Thalassemys ruetimeyeri has been recognized as a

58 junior synonym of the pleurosternid Dorsetochelys typocardium (Seeley, 1869) (Milner, 2004;

59 Pérez-García, 2014). Thalassemys marina has long been considered to represent a eurysternid

60 (see Discussion), but Anquetin, Püntener \& Billon-Bruyat (2014) recently challenged this

61 conclusion and confirmed the validity of this taxon. As a result, Th. hugii and Th. marina are

62 currently considered as the only two valid thalassemydids. Undetermined Thalassemys remains

63 have been recently reported from the Kimmeridgian near Oker, Lower Saxony, Germany

64 (Marinheiro \& Mateus, 2011), and from the Kimmeridgian of the Isle of Purbeck, Dorset, 65 southern England (Pérez-García, 2015).

66 In the present study we describe two new specimens of Thalassemys (MJSN SCR011-87 and

67 MJSN BSY008-905) from the upper Kimmeridgian of Porrentruy, Canton of Jura, Switzerland.

68 They were recently discovered within the scope of the Paleontology A16 project, which aims to

69 rescue the paleontological material found during the construction of the A16 Transjurane

70 highway. The excavations resulted in a rich and diverse vertebrate fossil collection from the

71 Kimmeridgian, notably including extensive dinosaur trackways (Marty \& Hug, 2003; Marty et

72 al., 2007; Marty, 2008; Marty \& Billon-Bruyat, 2009) and numerous coastal marine turtles

73 (Billon-Bruyat, 2005; Püntener et al., 2014; Anquetin, Püntener \& Billon-Bruyat, 2015). MJSN

74 SCR011-87, an articulated, sub-complete shell with an associated scapula, is referred to a new

75 species, Thalassemys bruntrutana $\mathrm{n}$. sp. In contrast, MJSN BSY008-905, which consists of

76 disarticulated shell elements and a partial scapula, is referred to the type species Th. hugii. 
77 Furthermore, we discuss the implications of the new material from Porrentruy for the taxonomy

78 and paleobiogeography of Thalassemys.

80 GEOLOGICAL SETTING

81 The new Thalassemys specimens were collected near the village of Courtedoux, along the A16

82 Transjurane highway in the Ajoie Region, Canton of Jura, NW Switzerland (Fig. 1). MJSN

83 SCR011-87 was discovered in Sur Combe Ronde (SCR) in 2011, and MJSN BSY008-905 in

84 Bois de Sylleux (BSY) in 2008. Both specimens come from the Lower Virgula Marls

85 (Reuchenette Formation, Chevenez Member) that are dated from the Eudoxus ammonite zone

86 (Comment et al., in press) (Fig. 2). The Lower Virgula Marls are slightly older than the

87 Solothurn Turtle Limestone, which forms the uppermost member of the Reuchenette Formation

88 and is dated from the Autissiodorensis ammonite zone (Meyer, 1994; Comment, Ayer \& Becker, 89 2011).

90 MJSN SCR011-87 was embedded in a hardground within the Lower Virgula Marls (Fig. 2).

91 The reddish and strongly encrusted (Ostreidae, Serpulidae) hardground is dated from the

92 Orthocera ammonite horizon (Comment et al., in press). Its invertebrate fauna includes

93 brachiopods (Sellithyris) and benthic bivalves (Ceratomya, Pholadomya), the latter being

94 responsible for the hardgrounds undulated surface. Apart from this sub-complete shell,

95 vertebrates are limited to isolated material (chondrichthyans, osteichthyans, turtles, crocodilians)

96 and two well preserved crocodilian skeletons (Metriorhynchus sp. and Steneosaurus cf.

97 bouchardi; Schaefer, 2012; Schaefer \& Billon-Bruyat, 2014).

98 MJSN BSY008-905 comes from a marly interval of the Lower Virgula Marls that is slightly

99 younger (Hibridus ammonite horizon) than the aforementioned hardground (Koppka, 2015; 
100 Comment et al., in press) (Fig. 2). This about $1 \mathrm{~m}$-thick brown marl yielded a rich and diverse

101 coastal marine assemblage, including invertebrates (bivalves, gastropods, cephalopods,

102 crustaceans, and echinoderms), vertebrates (chondrichthyans, osteichthyans, turtles, crocodilians,

103 and pterosaurs), and wood remains (Billon-Bruyat, 2005; Marty \& Billon-Bruyat, 2009; Philippe

104 et al., 2010; Koppka, 2015).

105

106

NOMENCLATURAL ACTS

107 The electronic version of this article in Portable Document Format (PDF) will represent a

108 published work according to the International Commission on Zoological Nomenclature (ICZN),

109 and hence the new names contained in the electronic version are effectively published under that

110 Code from the electronic edition alone. This published work and the nomenclatural acts it

111 contains have been registered in ZooBank, the online registration system for the ICZN. The

112 ZooBank LSIDs (Life Science Identifiers) can be resolved and the associated information viewed

113 through any standard web browser by appending the LSID to the prefix "http://zoobank.org/".

114 The LSID for this publication is: urn:lsid:zoobank.org:pub:5206D70B-E07B-42A0-AF98-

115 E0371DD491D5. The online version of this work is archived and available from the following

116 digital repositories: PeerJ, PubMed Central and CLOCKSS.

117

118 SYSTEMATIC PALEONTOLOGY

119 TESTUDINES Batsch, 1788

120 PANCRYPTODIRA Joyce, Parham \& Gauthier, 2004

121 THALASSEMYDIDAE Zittel, 1889 
122 Remark. Thalassemydidae is currently a monogeneric family. Since 2014, we are engaged in a

123 global revision of European Late Jurassic coastal marine turtles (this represents more than 60

124 named species in the literature), which are traditionally referred to three families:

125 Plesiochelyidae, Eurysternidae and Thalassemydidae. The characteristics and potential

126 relationships of these three families are still obscure. Early on, we decided to take a conservative

127 path and keep on using these three family names in their traditional definition until we have

128 gathered enough knowledge about their phylogenetic relationships (Anquetin, Püntener \&

129 Billon-Bruyat, 2014). The purpose was to avoid havocking supra-generic classification at each

130 new paper, especially without phylogenetic justification.

131 Thalassemys Rütimeyer, 1873

132 Type species. Thalassemys hugii Rütimeyer, 1873

133 Included valid species. Thalassemys hugii Rütimeyer, 1873; Thalassemys marina Fraas, 1903;

134 Thalassemys bruntrutana $\mathrm{n} . \mathrm{sp}$.

135 Occurrence. Kimmeridgian of Switzerland (Rütimeyer, 1873; Bräm, 1965; this study), Germany

136 (Marinheiro \& Mateus, 2011), and England (Pérez-García, 2015; Pérez-García, in press);

137 Tithonian of Germany (Fraas, 1903).

138 Revised diagnosis. Type and only genus of Thalassemydidae. Medium to large sized turtle

139 (estimated carapace length up to $700 \mathrm{~mm}$ ); relatively flat carapace (as opposed to the more

140 domed plesiochelyid carapace); presence of clearly visible linear striations perpendicular to most

141 sutures on the carapace and plastron. Differing from Plesiochelys, Craspedochelys Rütimeyer,

142 1873, and Tropidemys Rütimeyer, 1873 in: presence of small costo-peripheral fontanelles in the

143 adult; presence of lateral plastral fontanelles; non-sutural connection of epi- and entoplastron;

144 presence of a small fontanelle between the xiphiplastra; wider angle between scapular process 
145 and acromion process (only known in Plesiochelys). Differing from Idiochelys Meyer, 1839a,

146 Eurysternum Meyer, 1839b, and Solnhofia Gaffney, 1975 in: larger size; narrower vertebral

147 scales; osseous bridge; complete series of neurals (incomplete in Idiochelys); central plastral

148 fontanelle present (absent in Idiochelys) and longer than wide (opposite in Eurysternum); small

149 xiphiplastral fontanelle present (absent in Idiochelys and Solnhofia).

150 Remarks. Thalassemys differs from other Late Jurassic turtles from Europe by a combination of

151 several features. A striking character is the presence of distinct linear striations perpendicular to

152 sutures (Anquetin, Püntener \& Billon-Bruyat, 2014). This somewhat recalls the condition known

153 in the Early Cretaceous Pleurosternon bullockii Owen, 1842 (see Milner, 2004), but these

154 striations are more pronounced in Thalassemys. In contrast, they are absent (or only very weakly

155 expressed) in plesiochelyids and eurysternids. The shape of vertebral scales is also characteristic

156 of Thalassemys. The anterolateral sides of vertebrals $2-4$ are slightly concave, whereas the

157 posterolateral sides are either slightly convex or sub-straight. The plastral anatomy of

158 Thalassemys clearly differentiates it from plesiochelyids and eurysternids. In contrast to

159 plesiochelyids, lateral plastral fontanelles occur in Thalassemys and there is no sutural

160 connection of the epiplastra and entoplastron with the hyoplastra. In contrast to eurysternids, the

161 bridge of Thalassemys is osseous. As previously proposed by Bräm (1965), the angle between

162 the scapular and acromion processes of the scapula may also be a distinguishing feature of

163 Thalassemys. This angle is more open in Thalassemys $\left(113-130^{\circ}\right)$ than in Plesiochelys etalloni

164 (Pictet \& Humbert, 1857) $\left(103-105^{\circ}\right)$, but a broader survey of Late Jurassic coastal marine

165 turtles is needed to definitely conclude on this character variation (Table 1).

166 Anquetin, Püntener \& Billon-Bruyat (2014) suggested that a strong anterior widening of the

167 first neural was diagnostic for Thalassemys. This feature is present in most specimens referred to 
168 Th. hugii, as well as in the type specimens of Th. marina and Th. bruntrutana. However,

169 Thalassemys specimens from England (NHMUK R8699 and OUMNH J.66966; see Discussion)

170 and one specimen of Th. hugii from Solothurn (NMS 8555) lack a strong anterior widening of

171 the first neural. This feature is therefore probably variable intraspecifically.

172

173 Thalassemys hugii Rütimeyer, 1873

174 Synonymy. Thalassemys Gresslyi Rütimeyer, 1873 and Eurysternum ignoratum Bräm, 1965

175 (Anquetin, Püntener \& Billon-Bruyat, 2014).

176 Type material. NMS 8595-8609, almost complete and articulated carapace, disarticulated

177 plastral fragments, postcranial remains. Lectotype designated by Bräm (1965: 143).

178 Illustrations of type. Rütimeyer (1873: plate I); Bräm (1965: plate 7); Anquetin, Püntener \&

179 Billon-Bruyat (2014: figs. 6A-6D); Figs. 3C-3D, 6C-6D and 7C-7D.

180 Type horizon and locality. Solothurn Turtle Limestone, uppermost member of the Reuchenette

181 Formation (Autissiodorensis ammonite zone, upper Kimmeridgian, Late Jurassic), vicinity of

182 Solothurn, Canton of Solothurn, Switzerland.

183 Occurrence. Kimmeridgian of Switzerland (Solothurn and Porrentruy) and England (Abingdon).

184 Referred specimens. All specimens referred by Bräm (1965) and Anquetin, Püntener \& Billon-

185 Bruyat (2014), except for NMS 9144 and NMS 37251; NMS 22286-22302 (material from the

186 Solothurn St Niklaus quarry); MJSN BSY008-905 (Figs. 8A-8F); OUMNH J.66966 (Pérez-

187 García, in press; see Discussion).

188 Diagnosis. Differing from Th. bruntrutana in: proportionally wider nuchal with no anterolateral

189 thickening on ventral surface; narrower vertebral scales; proportionally smaller plastron;

190 narrower and more inclined xiphiplastron; smaller angle between scapular process and acromion 
191 process. Differing from Th. marina in: narrower vertebrals scales; less pronounced lateral

192 plastral fontanelles.

193

194 Thalassemys bruntrutana sp. nov.

195 urn:lsid:zoobank.org:act:E3FB882C-BD2B-4C6F-84EE-365033729E74

196 Figs. 3A-3B, 4A-4B, 5A-5C, 6A-6B, and 7A-7B

197 Etymology. The species name refers to the German form of the name Porrentruy (Pruntrut),

198 possibly derived from Bruntrutum (meaning abundant springs) (Schweizerische Bundeskanzlei,

199 2015). This name is also a homage to Jules Thurmann (1804-1855), a renowned local geologist

200 and botanist, for its fundamental paleontological work Lethea bruntrutana that was published

201 after his death (Thurmann \& Etallon, 1861-1864).

202 Holotype. MJSN SCR011-87, an almost complete and articulated carapace (peripherals and

203 nuchal disarticulated), disarticulated plastron, and left scapula.

204 Type horizon and locality. Lower Virgula Marls, Chevenez Member, Reuchenette Formation

205 (Eudoxus ammonite zone, upper Kimmeridgian, Late Jurassic), vicinity of Porrentruy

206 (Courtedoux village), Canton of Jura, Switzerland (Comment et al., in press).

207 Occurrence. Kimmeridgian of Switzerland (Porrentruy and Solothurn) and England (Isle of

208 Purbeck).

209 Referred specimens. NMS 9144 and NMS 37251; NHMUK R8699.

210 Diagnosis. Differing from Th. hugii in: more elongated nuchal (in anteroposterior direction) that

211 strongly thickens anterolaterally on the ventral surface; wider vertebrals scales; proportionally

212 longer plastron; broader and less inclined xiphiplastron; wider angle between scapular process 
213 and acromion process. Differing from Th. marina in: wider vertebrals scales; less pronounced

214 lateral plastral fontanelles.

215

216 MJSN SCR011-87 (THALASSEMYS BRUNTRUTANA)

\section{General preservation}

218 MJSN SCR011-87 consists of an almost complete carapace and plastron associated with the left

219 scapula. The neural series is almost complete and still in articulation with the costals. The nuchal

220 and most of the peripherals are preserved as disarticulated elements. The remaining peripherals,

221 the suprapygals and the pygal are missing. The different elements of the plastron are

222 disarticulated. Epiplastra and entoplastron are missing. The uneven and fractured surface is

223 yellowy-white in color with orange-to-reddish patches (iron mineralizations, mainly on the

224 carapace) and black spots (manganese), the latter occasionally forming tiny dendrites along

225 fractures. There are several traces of serpulids, mainly on the surface of the detached peripherals.

226 Being broad but shallow, the scale sulci are not always easy to discern. Distinct linear striations

227 extend perpendicular to sutures (mainly in anteroposterior direction), as observed in Th. hugii

228 and Th. marina (Anquetin, Püntener \& Billon-Bruyat, 2014). These striations are the most

229 striking at the hyo-hypoplastron suture.

230

231 Carapace

232 As preserved, the (sub-complete) carapace measures $477 \mathrm{~mm}$ in length along the midline and

$233531 \mathrm{~mm}$ on the maximal width (at the level of costals 3-4). These dimensions are comparable to

234 that of the lectotype of Th. hugii (NMS 8595-8609; Fig. 3). NMS 8595-8609 has a preserved

235 length of about $630 \mathrm{~mm}$ (Bräm, 1965). However, without the nuchal and the two suprapygals 
236 (elements that are disarticulated or missing in MJSN SCR011-87), it reaches a length of $470 \mathrm{~mm}$.

237 With $530 \mathrm{~mm}$ (Bräm, 1965), NMS 8595-8609 has furthermore almost the same preserved width 238 as MJSN SCR011-87 (both specimens missing the peripherals on either side of the carapace).

239 Individual bone measurements (neurals, costals) confirm that MJSN SCR011-87 and NMS $2408595-8609$ are approximately of the same size (Table S1). MJSN SCR011-87 is clearly larger 241 than the holotype of Th. marina (SMNS 10817). However, the ontogenetic stage of SMNS 24210817 is unknown.

243 The shell is unusually flat. This can be partially explained by taphonomic compaction, 244 which notably flattened the carapace medially along the neurals. However, there are no 245 important openings between the costals, which suggests that the compaction was only moderate. 246 The original carapace vaulting must have been similar to that of Th. hugii (NMS 8595-8609), 247 which is less affected by taphonomic compaction and therefore slightly more domed. Compared 248 to Th. bruntrutana and Th. hugii, the carapaces of plesiochelyids (e.g., Plesiochelys etalloni or 249 Tropidemys langii Rütimeyer, 1873) are clearly more domed.

250 As preserved, the carapace is roundish in outline, but the missing rim elements (especially 251 the suprapygals and pygal) prevent an accurate reconstruction of the original outline (Figs. 3A 252 and 3B). Bräm (1965) reconstructed the carapacial outline of Th. hugii as slightly heart-shaped, 253 but most of the specimens he had at hand were either too incomplete or missing their peripherals. 254 In contrast, based on undescribed material from Solothurn, Lapparent de Broin, Lange-Badré \& 255 Dutrieux (1996) suggested that the carapace of Th. hugii had an oval outline. However, the exact 256 carapacial outline of Th. hugii and Th. marina remains uncertain. 
259 The exact outline of the disarticulated nuchal cannot be reconstructed (Fig. 4A). It is roughly

260 rectangular and proportionally more elongated than the nuchal of Th. hugii (e.g., NMS 8595-

2618609 ; Fig. 3D). There is no nuchal notch. The uneven notch on the anterior border of the nuchal

262 is clearly a fracture. A wide embayment on the posterior border of the nuchal once held the first

263 neural. The nuchal bone is thickening strongly anterolaterally on the visceral side (Fig. 4B). This

264 distinctive feature is absent in Th. hugii (see Discussion).

265

266 Neurals

267 There are eight neurals (Fig. 3A and 3B). The first one misses its anterior part, but the wide

268 embayment on the posterior border of the nuchal (see above) indicates a strong widening of the

269 first neural towards the anterior. The following neurals are roughly hexagonal in outline with the

270 shorter sides facing anteriorly (except for neural 8). Neurals 2 and 3 are twice as long as wide.

271 Neurals $4-8$ are then successively shorter in proportion, neural 8 being clearly wider than long.

272 The bone posterior to neural 8 is herein interpreted as the 'intermediate' element, as described in

273 Th. hugii and several plesiochelyids (Anquetin, Püntener \& Billon-Bruyat, 2014).

274

275 Costals

276 Costals $2-5$ are completely preserved on each side of the carapace (Figs. 3A and 3B). In contrast,

277 costals 1 have incomplete anterior borders, whereas costals 6-8 lack their lateral parts. The

278 posterior border is convex posteriorly in costals 1 and 2 , but concave posteriorly in costals $3-8$.

279 As an individual variation, the distal margin of the left costal 2 is clearly longer than that of its

280 right counterpart. The lateral borders of costals $2-5$ as well as the posterolateral border of the

281 first costal do not show any sign of suture, indicating a cartilaginous contact with the peripherals 
282 (possibly with minor costo-peripheral fontanelles). Although damaged by abrasion, the preserved

283 anterolateral border of the right costal 1 suggests a sutural connection with peripherals 1 and 2.

284 In Th. hugii, the first three peripherals are sutured to the first and second costals, but the

285 condition for other peripherals remains uncertain (NMS 8595-8609; Figs. 3C and 3D).

286

\section{Peripherals}

288 Among the disarticulated bone elements, seventeen peripherals or parts of peripherals have been 289 identified (Fig. 5). However, their precise position in the carapace cannot be evaluated, mainly 290 due to the poor preservation and the absence of sutural contacts between most peripherals and 291 costals. Some of these peripherals are still partly articulated with one another (Figs. 5A and 5B).

292 The largest peripheral of the bridge area reaches $100 \mathrm{~mm}$ in length and $80 \mathrm{~mm}$ in width. 293

\section{Scales of the carapace}

295 As often, scale sulci are difficult to discern on the nuchal bone. One cervical scale can be 296 discerned on the anteromedial part of the nuchal (Fig. 4A). It is about $30 \mathrm{~mm}$ long and $50 \mathrm{~mm}$ 297 wide. However, the poor surface preservation impedes a conclusion about the actual number of 298 cervicals. Anquetin, Püntener \& Billon-Bruyat (2014) suggested that three cervicals may have 299 been present in Th. hugii (based on NMS 8595-8609).

300 Five vertebrals are present (Fig. 3B). The first vertebral is wider than the nuchal and would 301 have reached the (missing) first peripherals anterolaterally. Vertebrals 2 and 3 are hexagonal in 302 shape with posterolateral margins shorter than anterolateral ones. This can also be observed in 303 Th. marina (SMNS 10817). In Th. hugii, the anterolateral and posterolateral sides tend to be of 304 similar length (e.g., NMS 8595-8609, NMS 8555 and NMS 8997), but some variation may exist 
305 for this character (e.g., OUMNH J.66966). In Th. bruntrutana, vertebrals 2 and 3 are about twice

306 as wide as long and cover about half of the costal width. They are proportionally slightly wider

307 than in Th. marina and significantly wider than in Th. hugii, where they cover only about one

308 quarter to one third of the costal width (e.g., NMS 8595-8609, NMS 8612-8627 and NMS

309 8733). Vertebral 4 is the longest in the series. Its anterolateral sides are mostly straight. The

310 outline of vertebral 5 is not preserved. The intervertebral scale sulci are concave posteriorly and

311 cross neurals $1,3,5$, and the 'intermediate' element.

312 Pleurals 1-3 can partially be discerned (Fig. 3B). Although their lateral borders are missing,

313 it is evident that they are narrower than vertebrals $2-4$. The interpleural $1 / 2$ and $2 / 3$ sulci are

314 situated on the posterior parts of costals 2 and 4, running parallel to the intercostal sutures.

315 Pleurals 4 are not preserved.

316

317 Plastron

318 The hyo-, hypo-, and xiphiplastra are preserved and mostly complete (Figs. 6A and 6B), but the

319 epiplastra and entoplastron are missing. The lateral parts of the hyo- and hypoplastra now lie

320 within the same plane as the rest of the plastron, due to taphonomic compaction. As preserved,

321 the plastron is as wide as long (maximal preserved length $=510 \mathrm{~mm}$; maximal preserved width $=$

$322510 \mathrm{~mm}$ ). Thalassemys bruntrutana has a proportionally longer plastron than Th. hugii. Despite

323 the almost identical carapace size (see above), the plastron of MJSN SCR011-87 is measurably

324 longer than the one of NMS 8595-8609 (Figs. 6C and 6D), which has a maximal preserved

325 length of $430 \mathrm{~mm}$. The length of the bridge measured between the axillary and inguinal notches

326 is also more important in Th. bruntrutana (225 mm in MJSN SCR011-87) than in Th. hugii

327 (190 mm in NMS 8595-8609). 


\section{Hyo- and hypoplastra}

330 The hyoplastra are wider than long (Figs. 6A and 6B). A several centimeters wide, obconical

331 notch that once hold the missing entoplastron separates the hyoplastra anteromedially, whereas

332 an elongated central plastral fontanelle separates them posteromedially. In between, on a length

333 of about $50 \mathrm{~mm}$, the hyoplastra meet along an undulating contact. Anteriorly, there is no

334 evidence of sutural contact with the epiplastra and entoplastron.

335 The hypoplastra are more than twice as wide as long (Figs. 6A and 6B). Separated

336 anteromedially by the central plastral fontanelle, they meet on the posterior $65 \mathrm{~mm}$ of their

337 length along an undulating contact. Only about one third of the central plastral fontanelle lies

338 between the hypoplastra, where it is squarish to roundish in shape, in contrast to the longer,

339 rather oval part between the hyoplastra. The lateral margins of the hyoplastra are severely

340 damaged, but the hypoplastra show clear evidence for lateral fontanelles on their anterolateral

341 borders (Figs. 6A and 6B). Based on NMS 8595-8609, Bräm (1965) reconstructed the plastron

342 of Th. hugii without lateral fontanelles, but with an extensive central fontanelle that completely

343 separates the hyo- and hypoplastra. In this reconstruction, only the posterior parts of the

344 xiphiplastra are connected medially. However, the preservation of this specimen does not allow

345 to conclude either to the absence of a lateral plastral fontanelle, or to the size and shape of the

346 central plastral fontanelle (Figs. 6C and 6D). Isolated elements from Solothurn (e.g., NMS

347 22325) clearly indicate that $T h$. hugii indeed possesses a lateral plastral fontanelle and an

348 interdigitating contact between the hyoplastra (Anquetin, Püntener \& Billon-Bruyat, 2014),

349 refuting Bräm's reconstruction. We have detected new plastral material of Th. hugii from the St

350 Niklaus quarry in the Solothurn collections (NMS 22286, NMS 22287, and NMS 22296; 
351 possibly from the same individual as NMS 22325) that confirm the observations of Anquetin,

352 Püntener \& Billon-Bruyat (2014), but it remains uncertain whether the hypoplastra met medially

353 in Th. hugii, as in Th. bruntrutana and Th. marina. The lateral plastral fontanelles of Th. marina

354 are clearly more pronounced than in Th. bruntrutana and Th. hugii.

355

356 Xiphiplastra

357 The xiphiplastra, which are still connected to the hypoplastra by suture, are long elements (about

358 twice as long as wide) that are narrowing strongly posteriorly (Figs. 6A and 6B). They are

359 clearly separated by a fontanelle anteromedially and by a small anal notch posteromedially. It is

360 unclear whether the xiphiplastra actually met one another medially. The xiphiplastra are not as

361 strongly inclined (in relation to the anteroposterior axis of the plastron) as in Th. hugii (e.g.,

362 NMS 8595-8609; Figs. 6C and 6D). Compared to Th. hugii, the xiphiplastra are also broader

363 anteriorly at the contact to the hypoplastra.

364

365 Scales of the plastron

366 Scale sulci are only partially preserved (Fig. 6B). They show no important differences from $T h$.

367 hugii (e.g., NMS 8595-8609; Fig. 6D). The limit between humeral and pectoral scales lies

368 slightly anterior to the level of the deepest point of the axillary notches. The pectorals are slightly

369 shorter than the preserved parts of the humerals. The hyo-hypoplastral suture divides the

370 abdominal scale in about two equally sized parts. The femoral-anal sulcus is not preserved. Of

371 the inframarginal scutes, only the medial borders are partly preserved.

372

373 Scapula 
374 Only the left scapula is preserved (Figs. 7A and 7B). The glenoid fossa is only poorly preserved

375 and partly filled with sediment. The dorsally projecting scapular process is complete. It measures

$376140 \mathrm{~mm}$ from the dorsal end to the notch between the acromion process and the coracoid. It is

377 only slightly longer than the scapular process of NMS 8595-8609 (Th. hugii; $135 \mathrm{~mm}$; Figs. 7C

378 and 7D). The scapular process forms an angle of $130^{\circ}$ with the acromion process. Due to minor

379 post-mortem deformation, the scapular process and acromion process do not lie exactly in the

380 same plane, which might have a slight influence on the measured angle. In Th. hugii, this angle is

381 always smaller than in Th. bruntrutana (Table 1).

382

383

MJSN BSY008-905 (THALASSEMYS HUGII)

384 Carapace

385 The carapace of specimen MJSN BSY008-905 is represented by the nuchal, neurals 3-5, left

386 costals $2-3$, right costal 5 , right peripherals $1-2$, and nine other peripherals or parts of peripherals

387 (Figs. 8A and 8B). All elements of the carapace are disarticulated. The bone surface is brownish-

388 gray with distinct linear striations perpendicular to sutures. This specimen is smaller than the

389 lectotype of Th. hugii (about 85\% of the size of NMS 8595-8609 based on individual bone

390 measurements).

391

392 Nuchal

393 The nuchal of MJSN BSY008-905 (Figs. 8A and 8B) is roughly trapezoidal in outline and about

394 twice as wide as long. Anteriorly, there is a broad and very shallow nuchal notch. The ventral

395 surface of the nuchal is flat and lacks anterolateral thickenings. These are characteristics of $T h$. 
396 hugii and clearly exclude MJSN BSY008-905 from Th. bruntrutana. A wide embayment on the 397 posterior border of the nuchal once held the first neural.

398 The anterolateral borders of the nuchal are emarginated in order to hold an anteromedial

399 projection of the first peripherals. Such emarginations are usually absent in Th. hugii, but they

400 occur in the specimen OUMNH J.66966 from the Kimmeridge Clay (Pérez-García, in press; see

401 Discussion). Püntener et al. (2014) reported a comparable morphology in one specimen of

402 Tropidemys langii from Porrentruy, although in this specimen small supernumerary bones

403 articulate with the nuchal in this area. This morphology is therefore interpreted as an

404 intraspecific variation.

405

406 Neurals

407 The three preserved neurals are hexagonal in outline with shorter sides facing anteriorly (Figs.

$4088 \mathrm{~A}$ and $8 \mathrm{~B}$ ). The neural length decreases from neurals 3 to 5 , but all neurals remain clearly

409 longer than wide.

410

411 Costals

412 The lateral border of the second costal is rounded and smooth on the dorsal edge, but shows a

413 sutural contact on the visceral edge, suggesting the transition from a cartilaginous to a sutural

414 contact. Costals 3 and 5 do not show any sign of suture with the peripherals. Here, the contact to

415 the peripherals was fully cartilaginous and minor costo-peripheral fontanelles may have been

416 present. Costal 5 still possesses a laterally jutting rib (Figs. 8A and 8B). The closure of costo-

417 peripheral fontanelles is slightly less advanced than in the only sub-complete adult specimen of

418 Th. hugii (NMS 8595-8609; see Discussion). 


\section{Peripherals}

421 Out of the eleven preserved peripherals, the precise position of only two could be identified with 422 certainty: the right peripherals 1 and 2 (Figs. 8A and 8B). The posterior borders of peripherals $1-$ 4232 show a sutural contact to the anterior border of the missing first costal. The anteromedial 424 corner of peripheral 1 is reaching out to fit in the anterolateral emargination of the nuchal. The 425 second peripheral is squarish and contrasts with the elongated second peripheral in the lectotype of Th. hugii (NMS 8595-8609). However, the shape of peripherals is known to be variable in

427 other closely related taxa, for example in P. etalloni (Anquetin, Püntener \& Billon-Bruyat, 428 2014).

429

430 Scales of the carapace

431 Cervical scales are only weakly expressed. There is probably a medial cervical scale that is about $43215 \mathrm{~mm}$ long and $35 \mathrm{~mm}$ wide (Fig. 8B). To its left, a narrower lateral cervical scale may have 433 been present. However, no trace of a lateral cervical scale is preserved on the right side. Hence, 434 the actual number of cervicals is not conclusive in this specimen. The second vertebral covers 435 about one quarter to one third of the width of costal 3 and the third vertebral covers slightly more 436 than one third of the width of costal 5 (Fig. 8B). This is congruent with other specimens referred 437 to Th. hugii, but clearly narrower than in Th. bruntrutana (where vertebral scales cover about 438 half of the costal width) and Th. marina. There is no trace of the intervertebral $3 / 4$ scale sulcus 439 on costal 5 , nor on neural 5 , suggesting a shift of this sulcus onto costal 6 and neural 6 440 respectively. Such a shift is known to occur occasionally in other taxa, for example in Tr. langii 441 (Püntener et al., 2014). 
Plastron

444 Of the plastron, only parts of the left hyoplastron, right hypoplastron, and right xiphiplastron are 445 preserved (Figs. 8C and 8D). The bridge length is estimated to be around $170 \mathrm{~mm}$. As most

446 borders are broken, the presence of neither lateral nor central fontanelles can be confirmed in this

447 specimen. As in other specimens referred to Th. hugii, the lateral border of the xiphiplastron is 448 strongly inclined relative to the anteroposterior axis of the plastron, which clearly contrasts with 449 the condition in Th. bruntrutana.

\section{Scapula}

452 A small portion of the (left?) scapula is preserved (Figs. 8E and 8F). The distal part of the 453 scapular and acromion processes is missing, as well as the glenoid. The angle between the 454 scapular and acromion processes is about $116^{\circ}$. This falls within the range measured for $T h$. 455 hugii and contrasts with the larger angle observed in Th. bruntrutana (Table 1).

\section{DISCUSSION}

\section{Alpha taxonomy of Thalassemys}

459 In the present study, three species of Thalassemys are considered valid: Th. hugii, Th. marina, 460 and the new species Th. bruntrutana. Thalassemys hugii, the type species, is based on a

461 relatively complete shell associated with some postcranial elements (NMS 8595-8609) from the

462 late Kimmeridgian of Solothurn, Switzerland (Rütimeyer, 1873; Bräm, 1965). The validity of

463 this species has never been questioned. Thalassemys marina is based on a partial carapace and 464 plastron (SMNS 10817) from the Tithonian of Schnaitheim, Germany (Fraas, 1903). Based on 
465 the presence of a lateral plastral fontanelle, Bräm (1965) and Maisch (2001) referred this species 466 to the genus Eurysternum. However, it was later demonstrated that a lateral plastral fontanelle 467 was also present in Th. hugii (Anquetin, Püntener \& Billon-Bruyat, 2014). Joyce (2003) 468 tentatively synonymized Thalassemys marina with Palaeomedusa testa Meyer, 1860 based on 469 the purported presence of supernumerary pleural scales in SMNS 10817, but the specimen is 470 reconstructed in this area and this assertion does not withstand direct observation. Since SMNS 47110817 exhibits significant differences with specimens referred to Th. hugii and Th. bruntrutana 472 (see below), Th. marina must be considered a valid species.

473 The nuchal of Th. bruntrutana is remarkable in many aspects. It is significantly more 474 elongated than that of Th. hugii and it is characterized by the presence of a strong anterolateral 475 thickening of the ventral surface on both sides. Such morphology has never been observed in 476 other Late Jurassic coastal marine turtles from Europe. However, a similar condition has been 477 described in the lindholmemydid freshwater turtle Amuremys planicostata (Riabinin, 1930) from 478 the Late Cretaceous of Russia, for which it is considered a diagnostic feature (Danilov et al., 479 2002). The nuchal of Th. marina is not known.

480 The width of vertebral scales is another distinctive feature between species of the genus 481 Thalassemys. The vertebral scales of Th. hugii are narrow (covering $1 / 4$ to $1 / 3$ of the costal 482 bones), whereas the vertebral scales of Th. bruntrutana are distinctly wider (covering about 1/2 483 of the costals). The vertebral scales of Th. marina are somewhat intermediate in width between 484 those of Th. hugii and Th. bruntrutana. The width of vertebral scales is known to change during 485 ontogeny, usually decreasing from juveniles to adults (e.g., Joyce, 2007). However, it is 486 noteworthy that juvenile specimens of Th. hugii (e.g., NMS 8612-8627, NMS 8733, and NMS 487 8997) have the same narrow vertebral scales as the adults (e.g., NMS 8595-8609 and NMS 
488

489

490

491

492

493

494

495

496

497

498

499

500

501

502

503

504

505

506

507

508 Th. bruntrutana, the lateral plastral fontanelle is relatively narrow, even in juvenile specimens.

509 This probably explains why the presence of these fontanelles long went unnoticed in Th. hugii

8555). It must also be considered that the type specimens of Th. hugii and Th. bruntrutana are of similar size. Therefore, ontogeny cannot explain the clearly different width of vertebral scales in the two taxa. The case of Th. marina is more complicated since this species is known only by a single individual that is about $65 \%$ the size of the type specimens of the two other species.

However, two arguments allow the hypothesis that the holotype of Th. marina would be a juvenile of either Th. hugii or Th. bruntrutana to be rejected. First, as aforementioned, juveniles of Th. hugii have narrow vertebral scales. Second, given the general tendency toward the reduction of the vertebral scale width during ontogeny, juveniles of Th. bruntrutana would be expected to have vertebral scales that are wider than, or at least as wide as, those of the adults.

At comparable size, the suturing of costals 1 and 2 with adjoining peripherals is more advanced in Th. hugii than in Th. bruntrutana. For example, in the lectotype of Th. hugii (NMS 8595-8609) peripherals 1-3 are sutured to costals 1 and 2 at least up to the anterior half of

peripheral 3. In the holotype of Th. bruntrutana (MJSN SCR011-87; a similarly-sized specimen), only peripherals 1 and 2 are sutured with costal 1 , whereas the posterolateral border of costal 1 and costals 2-5 lack sutural contacts with the peripherals (see above). MJSN BSY008-905, a specimen we refer to $T h$. hugii, confirms this difference in the timing of costo-peripheral suturing between the two species. An incipient sutural contact between costal 2 and peripheral 3 is present in this specimen, although its size is only about $85 \%$ that of the holotype of Th. bruntrutana. This area is not preserved in Th. marina, which prevents comparison.

Lateral plastral fontanelles are present in all three species of Thalassemys. In Th. hugii and 
510 (see Anquetin, Püntener \& Billon-Bruyat, 2014). In contrast, the lateral plastral fontanelle is

511 significantly broader in Th. marina.

512 Thalassemys hugii is remarkable in the strong inclination of the lateral border of its

513 xiphiplastron relative to the anteroposterior axis of the plastron (Table 2). In Th. bruntrutana and

514 most other turtles, the lateral border of the xiphiplastron is significantly less inclined in relation

515 to the anteroposterior axis. The xiphiplastron is unknown in Th. marina. Two specimens from

516 Solothurn previously referred to Th. hugii (NMS 9144 and NMS 37251; see Anquetin, Püntener

$517 \&$ Billon-Bruyat, 2014) are herein tentatively referred to Th. bruntrutana based on the

518 morphology of their xiphiplastra (Table 2).

519 As noted by Bräm (1965), the angle between the scapular and acromion process of the

520 scapula is more open in Thalassemys than in the plesiochelyid Plesiochelys etalloni. Within

521 Thalassemys, the scapular angle ranges from $113^{\circ}$ to $122^{\circ}$ in specimens referred to Th. hugii

522 (including MJSN BSY008-905), whereas this angle reaches $130^{\circ}$ in the holotype of $T h$.

523 bruntrutana (Table 1). Although the scapular angle of Th. marina is unknown, it appears that this

524 measurement can be used to distinguish Th. hugii from Th. bruntrutana.

525 The potential effect of ontogeny and sexual dimorphism on our perception of the alpha

526 taxonomy of Thalassemys must be considered. As discussed above, ontogeny can be easily

527 dismissed to explain the differences between the three identified species. Sexual dimorphism was

528 considered seriously notably for Th. hugii and Th. bruntrutana, which are contemporaneous

529 species sometimes occurring in the same localities (see Paleobiogeographic considerations). In

530 recent turtles, sexual dimorphism is primarily expressed in a difference in shell size between

531 adult males and females (Berry \& Shine, 1980; Pritchard, 2008). Furthermore, adult males often

532 develop a concave plastron (in terrestrial species) and a shorter and wider anal notch (Pritchard, 
533 2008). In terms of fossil turtles, reports of sexual dimorphism are scarce and relate for instance to

534 the shape of the anal notch, to the size of the central plastral fontanelle (Cadena, Jaramillo \&

535 Bloch, 2013), to plastral kinesis, and to tail length (Joyce et al., 2012). All these differences are

536 directly linked to sexual selection (shell size), copulation (concave plastron, plastral fontanelle

537 size, shape of anal notch, tail length) or oviposition (shape of anal notch, plastral kinesis) (Berry

538 \& Shine, 1980; Pritchard, 2008; Joyce et al., 2012; Cadena, Jaramillo \& Bloch, 2013). In

539 contrast, we are unable to link any observed anatomical difference between Th. hugii and Th.

540 bruntrutana (e.g., the vertebral width or the nuchal shape) to reproductive behavior. Therefore,

541 we consider these differences as specific and interpret Th. hugii and Th. bruntrutana as two

542 closely related species.

543

544 Thalassemys from the Kimmeridge Clay Formation

545 Recently, Pérez-García (2015) discussed a relatively complete, but strongly flattened carapace of

546 Thalassemys with associated postcranial remains from the Kimmeridge Clay Formation (late

547 Kimmeridgian) of Egmont Bight, Isle of Purbeck, Dorset, England (NHMUK R8699). Based on

548 the presence of linear striations perpendicular to sutures and the characteristic outline of the

549 vertebral scales, we agree that this specimen belongs to Thalassemys. Pérez-García (2015) noted

550 some differences between this specimen and the lectotype of Th. hugii (smaller size, wider

551 vertebral scales, and more developed costo-peripheral fontanelles) and safely concluded that no

552 specific determination was possible for this specimen at that time. NHMUK R8699 and the

553 holotype of Th. bruntrutana (MJSN SCR011-87) have several features in common. Although

554 NHMUK R8699 is only about 65\% the size of MJSN SCR011-87, both specimens have vertebral

555 scales of the same proportions (about twice as wide as long) and shape (clearly longer 
556 anterolateral sides). As discussed above, the vertebral width likely represents a specific character

557 within Thalassemys, in that case uniting NHMUK R8699 with Th. bruntrutana and

558 distinguishing it from Th. hugii and Th. marina. The scapular angle measured on NHMUK

559 R8699 is relatively small (about $103^{\circ}$; not $115^{\circ}$ as incorrectly noted by Pérez-García, 2015), but

560 it should be noted that this specimen has been severely flattened during fossilization: all bones

561 and shell plates are flat and thin. This measured angle probably does not reflect the original

562 scapular angle in this specimen. As discussed above, we can also observe a very slight

563 deformation of the scapula of MJSN SCR011-87. However, NHMUK R8699 has clearly been

564 more flattened during fossilization. There is almost no volume in the scapula, indicating a really

565 strong deformation. Keeping in mind this uncertainty and the fact that several important parts of

566 the shell (nuchal, plastron) are missing, we tentatively refer NHMUK R8699 to Th. bruntrutana

567 and thereby report the presence of this species in the Kimmeridgian of southern England.

568 In 1992, Richard Wilkins, an amateur geologist, discovered the partial shell and some

569 postcranial elements of a large turtle in the Kimmeridge Clay of Abington, Oxfordshire,

570 England. He tentatively identified the specimen as a thalassemydid and donated it to the Oxford

571 University Museum, where it still resides today (OUMNH J.66966). This specimen was later

572 studied as part of a Master thesis and believed to be an indeterminate pleurodire (Harrison,

573 1999). However, this shell truly belongs to a thalassemydid and was recently referred to $T h$.

574 hugii (Pérez-García, in press). Based on the morphology of the nuchal, width of the vertebral

575 scales, and inclination of the xiphiplastron, we agree with this attribution.

576

577 Paleobiogeographic considerations 
578 The paleobiogeographic distribution of Late Jurassic coastal marine turtles in Europe is largely

579 unexplored. This is mainly the result of a poor understanding of the alpha taxonomy of these

580 turtles. A global revision of these groups at the European scale is needed. Until recently,

581 Thalassemys hugii was confidently identified only in Solothurn, Switzerland (Rütimeyer, 1873;

582 Bräm, 1965), whereas Th. marina was known by a single specimen from Schnaitheim, Germany

583 (Fraas, 1903). Recently, Pérez-García (in press) referred a specimen from the Kimmeridge Clay

584 of England to Th. hugii and proposed that a second, unidentified species of Thalassemys was also

585 present in the same formation.

586 In the present study, we identified a new thalassemydid from Porrentruy, Switzerland

587 (Thalassemys bruntrutana), and tentatively proposed that this species was also present in

588 Solothurn and the Isle of Purbeck (the unidentified specimen of Pérez-García, in press). We also

589 described a new specimen from Porrentruy that can be confidently identified as Th. hugii. Our

590 results therefore show that both Th. hugii and Th. bruntrutana are present in the Kimmeridgian

591 of the Swiss Jura Mountains (Solothurn and Porrentruy) and of southern England (Isle of

592 Purbeck and Abington; Fig. 9). This confirms the results of Pérez-García (in press). Thalassemys

593 hugii and Thalassemys bruntrutana represent the first Late Jurassic coastal marine turtles that are

594 demonstrated to have a Western European paleobiogeographic distribution. Such a result is not

595 surprising since some thalattosuchian crocodylomorphs that inhabit the same environments also

596 have a Western European distribution at that time, e.g., the large teleosaurid Machimosaurus

597 hugii Meyer, 1837 (Young et al., 2014; Martin et al., in press). We expect that future studies will

598 also extend the paleobiogeographic repartition of other Late Jurassic coastal marine turtles from

599 Europe.

600 
601

602

603

604

605

606

607

608

609

610

611

612

613 distribution. Thalassemys hugii and Th. bruntrutana are currently not identified in the German

614 fossil record, but the undetermined material of Thalassemys from the Kimmeridgian of Oker

615 (northern Germany; Marinheiro \& Mateus, 2011) should be analyzed in the light of the

616 Porrentruy material. So far, Th. marina from the Tithonian of Schnaitheim (southern Germany)

617 remains the only valid species of Thalassemys in Germany.

619 Institutional abbreviations

620 MJSN JURASSICA Museum (formerly Musée jurassien des sciences naturelles),

621

Porrentruy, Switzerland

622 NHMUK Natural History Museum, London, UK

623 NMS Naturmuseum Solothurn, Switzerland 
OUMNH Oxford University Museum of Natural History, Oxford, UK

625 SMNS

Staatliches Museum für Naturkunde Stuttgart, Germany

626

627 Locality abbreviations

628

BSY Courtedoux-Bois de Sylleux

629

SCR

Courtedoux-Sur Combe Ronde.

630

631

632

633

634

635

636

637

638

639

640

641

642

643

644

645

646

\section{ACKNOWLEDGEMENTS}

We thank Loïc Bocat (excavation), Renaud Roch (preparation), Olivier Noaillon and Bernard Migy (photographs), Pierre Widder (scientific drawings), Apolline Lefort (discussion on stratigraphy) and the whole Paleontology A16 team. Further thanks go to Silvan Thüring of the Naturmuseum Solothurn for providing access to the lectotype of $T$. hugii, and to Adán PérezGarcía for discussions on Thalassemys. Editor Mathew Wedel and the reviewers Walter Joyce and Márton Rabi provided very helpful comments.

\section{REFERENCES}

Anquetin J, Joyce WG. 2014. A reassessment of the Late Jurassic turtle Eurysternum wagleri (Eucryptodira, Eurysternidae). Journal of Vertebrate Paleontology 34(6):1317-1328.

Anquetin J, Püntener C, Billon-Bruyat J-P. 2014. A taxonomic review of the Late Jurassic eucryptodiran turtles from the Jura Mountains (Switzerland and France). PeerJ 2:e369. DOI: 10.7717/peerj.369.

Anquetin J, Püntener C, Billon-Bruyat J-P. 2015. Portlandemys gracilis n. sp., a new coastal marine turtle from the Late Jurassic of Porrentruy (Switzerland) and a reconsideration of 
plesiochelyid cranial anatomy. PLOS ONE 10(6):e0129193. DOI:

10.1371/journal.pone.0129193.

Batsch AJGC. 1788. Versuch einer Anleitung, zur Kenntniß und Geschichte der Thiere und Mineralien. Jena: Akademische Buchhandlung.

Baur G. 1888. Osteologische Notizen über Reptilien (Fortsetzung II). Zoologischer Anzeiger $11: 417-424$.

Berry JF, Shine R. 1980. Sexual Size Dimorphism and Sexual Selection in Turtles (Order Testudines). Oecologia 44:185-191.

655

Billon-Bruyat J-P. 2005. A "turtle cemetery" from the Late Jurassic of Switzerland [Abstract]. In: 3rd Swiss Geoscience Meeting. Zürich, 2005. 238.

Bräm H. 1965. Die Schildkröten aus dem oberen Jura (Malm) der Gegend von Solothurn. Schweizerische Paläontologische Abhandlungen 83:1-190.

Broin F de. 1994. Données préliminaires sur les chéloniens du Tithonien inférieur des calcaires lithographiques de Canjuers (Var, France). Geobios 16:167-175. DOI: 10.1016/S00166995(94)80031-6.

Cadena EA, Jaramillo CA, Bloch JI. 2013. New material of the platychelyid turtle Notoemys zapatocaensis from the Early Cretaceous of Colombia; implications for understanding Pleurodira evolution. In: Brinkman DB, Holroyd PA, and Gardner JD, eds. Morphology and Evolution of Turtles. Springer, 105-120. DOI: 10.1007/978-94-007-4309-0_8.

Comment G, Ayer J, Becker D. 2011. Deux nouveaux membres lithostratigraphiques de la Formation de Reuchenette (Kimméridgien, Ajoie, Jura suisse). Nouvelles données géologiques et paléontologiques acquises dans le cadre de la construction de l'autoroute A16 (Transjurane). Swiss Bulletin for Applied Geology 16/1 (Separatdruck):1-24. 
670 Comment G, Lefort A, Hantzpergue P, Koppka J. Le Kimméridgien d'Ajoie (Jura, Suisse):

671 lithostratigraphie et biostratigraphie de la Formation de Reuchenette. Revue de

$672 \quad$ Paléobiologie In Press.

673 Danilov IG, Bolotsky Yu L, Averianov AO, Donchenko IV. 2002. A new genus of

674 lindholmemydid turtle (Testudines, Testudinoidea) from the Late Cretaceous of the Amur 675 River Region, Russia. Russian Journal of Herpetology 9:155-168.

676 Dollo L. 1886. Première note sur les Chéloniens du Bruxellien (Eocène moyen) de la Belgique. 677 Bulletin du Musée Royal d'Histoire Naturelle de Belgique 4:75-100.

678 Fraas E. 1903. Thalassemys marina E. Fraas aus dem oberen weissen Jura von Schnaitheim 679 nebst Bemerkungen über die Stammesgeschichte der Schildkröten. Jahreshefte des Vereins 680 für vaterländische Naturkunde in Württemberg 59:72-104.

681 Gaffney ES. 1975. Solnhofia parsonsi, a new cryptodiran turtle from the Late Jurassic of 682 Europe. American Museum Novitates 2576:1-22.

683 Harrison G. 1999. Description of two new Kimmeridgian turtles: implications for marine 684 modifications and phylogenetic position. Master Thesis, University of Bristol.

685 Joyce WG. 2003. A new Late Jurassic turtle specimen and the taxonomy of Palaeomedusa testa 686 and Eurysternum wagleri. PaleoBios 23:1-8.

687 Joyce WG. 2007. Phylogenetic relationships of Mesozoic turtles. Bulletin of the Peabody 688 Museum of Natural History 48:3-102. DOI: 10.3374/0079$689 \quad$ 032X(2007)48[3:PROMT]2.0.CO;2.

690 Joyce WG, Parham JF, Gauthier JA. 2004. Developing a protocol for the conversion of rank691 based taxon names to phylogenetically defined clade names, as exemplified by turtles. 692 Journal of Paleontology 78:989-1013. 
693 Joyce WG, Micklich N, Schaal SFK, Scheyer TM. 2012. Caught in the act: the first record of

694 copulating fossil vertebrates. Biology Letters 8:846-848. DOI: 10.1098/rsbl.2012.0361.

695 Koppka J. 2015. Revision of the Bivalvia from the Upper Jurassic Reuchenette Formation,

696 Northwest Switzerland-Ostreoidea. Zootaxa 3927(1):1-117.

697 Lapparent de Broin F de. 2001. The European turtle fauna from the Triassic to the present.

698 Dumerilia 4:155-217.

699 Lapparent de Broin F de, Lange-Badré B, Dutrieux M. 1996. Nouvelles découvertes de

700 tortues dans le Jurassique supérieur du Lot (France) et examen du taxon Plesiochelyidae.

$701 \quad$ Revue de Paléobiologie 15:533-570.

702 Lydekker R. 1889. Catalogue of the Fossil Reptilia and Amphibia in the British Museum

703 (Natural History). Part III, The Order Chelonia. London: Trustees of the British Museum.

704 Maack GA. 1869. Die bis jetzt bekannten fossilen Schildkröten und die im oberen Jura bei

705 Kelheim (Bayern) und Hannover neu aufgefundenen ältesten Arten derselben.

$706 \quad$ Palaeontographica 18:193-338.

707 Maisch WM. 2001. Schildkröten (Reptilia: Testudines) aus dem Brenztaloolith des Oberen Jura

708 der Schwäbischen Alb (SW-Deutschland) in der Tübinger Sammlung. Jahreshefte der

709 Gesellschaft für Naturkunde in Württemberg 157:99-114.

710 Marinheiro J, Mateus O. 2011. Occurrence of the marine turtle Thalassemys in the

711 Kimmeridgian of Oker, Germany. Abstracts of the 71st Annual Meeting of the Society of

$712 \quad$ Vertebrate Paleontology 2011:151.

713 Martin JE, Vincent P, Falconnet J. The taxonomic content of Machimosaurus

714 (Crocodylomorpha, Thalattosuchia). Palevol In press. 
715 Marty D. 2008. Sedimentology, taphonomy, and ichnology of Late Jurassic dinosaur tracks from

716 the Jura carbonate platform (Chevenez-CombeRonde tracksite, NW Switzerland): insights

717 into the tidalflat palaeoenvironment and dinosaur diversity, locomotion, and palaeoecology.

$718 \quad$ Ph.D. Thesis, University of Fribourg, Switzerland. GeoFocus 21:1-278.

719 Marty D, Hug WA. 2003. Le Kimméridgien en Ajoie (Mésozoïque): premiers résultats de

720 fouilles et de recherches paléontologique sur le tracé de la Transjurane (A16). Actes de la

721 Société jurassienne d'émulation 2003:27-44.

722 Marty D, Billon-Bruyat J-P. 2009. Field-trip to the excavations in the Late Jurassic along the

723 future Transjurane highway near Porrentruy (Canton Jura, NW Switzerland): dinosaur

724 tracks, marine vertebrates and invertebrates [Abstract]. In: Billon-Bruyat J-P, Marty D,

725 Costeur L, Meyer CA, Thüring B, eds. Abstracts and Field Guides, 5th International

726 Symposium on Lithographic Limestone and Plattenkalk, Actes 2009 bis de la Société

727 jurassienne d'émulation. Porrentruy, Switzerland, 94-129.

728 Marty D, Ayer J, Becker D, Berger J-P, Billon-Bruyat J-P, Braillard L, Hug WA, Meyer

729 CA. 2007. Late Jurassic dinosaur tracksites of the Transjurane highway (Canton Jura, NW

730 Switzerland): overview and measures for their protection and valorization. Bulletin for

$731 \quad$ Applied Geology 12:75-89.

732 Meyer CA. 1994. Depositional environment and paleoecology of the Solothurn turtle limestone

733 (Kimmeridgian, Northern Switzerland). Geobios 27 (Supplement 1):227-236.

734 Meyer H von. 1837. Mittheilungen, an Professor Bronn gerichtet. Neues Jahrbuch für

735 Mineralogie, Geognosie, Geologie und Petrefakten-Kunde:557-562.

736 Meyer H von. 1839a. Idiochelys Fitzingeri, eine Schildkröte aus dem Kalkschiefer von

737 Kelheim. Beiträge zur Petrefacten-Kunde 1:59-74. 
738 Meyer H von. 1839b. Eurysternum Wagleri, Münster. Eine Schildkröte aus dem Kalkschiefer 739 von Solnhofen. Beiträge zur Petrefacten-Kunde 1:75-82.

740 Meyer H von. 1860. Zur Fauna der Vorwelt. Reptilien aus dem lithographischen Schiefer des

741 Jura in Deutschland und Frankreich. Frankfurt am Main: Heinrich Keller Verlag.

742 Milner AR. 2004. The turtles of the Purbeck Limestone Group of Dorset, Southern England.

743 Palaeontology 47:1441-1467. DOI: 10.1111/j.0031-0239.2004.00418.x.

744 Oertel W. 1924. Die Schildkrötenfauna des nordwestdeutschen oberen Jura. Paläontologische $745 \quad$ Zeitschrift 6:43-79.

746 Owen R. 1842. Report on British fossil reptiles, part II. Report for the British Association for the 747 Advancement of Science, Plymouth 1841 11:60-204.

748 Pérez-García A. 2014. Revision of the poorly known Dorsetochelys typocardium, a relatively 749 abundant pleurosternid turtle (Paracryptodira) in the Early Cretaceous of Europe. $750 \quad$ Cretaceous Research 49:152-162.

751 Pérez-García A. 2015. New data on the poorly-known Late Jurassic European turtles

752 Thalassemys and Enaliochelys and description of a new basal eucryptodiran taxon. Journal 753 of Iberian Geology 41(1):21-30.

754 Pérez-García. Largest shell of a basal eucryptodiran turtle reveals Late Jurassic Thalassemys 755 hugii in the British record. Comptes Rendus Palevol In press.

Philippe M, Billon-Bruyat J-P, Garcia-Ramos JC, Bocat L, Gomez B, Piñuela L. 2010. New occurrences of the wood Protocupressinoxylon purbeckensis Francis: implications for terrestrial biomes in southwestern Europe at the Jurassic/Cretaceous boundary. Palaeontology 53:201-214. 
760 Pictet F-J, Humbert A. 1857. Description d'une émyde nouvelle (Emys Etalloni) du terrain

761 jurassique supérieur des environs de St-Claude. In: Pictet F-J, ed. Matériaux pour la

762 paléontologie suisse, Première série. Genève: J. Kessmann, 1-10.

763 Pritchard P. 2008. Evolution and structure of the turtle shell. In: Wyneken J, Godfrey M, Bels

764 V, eds. Biology of turtles. Boca Raton: CRC press, 45-83.

765 Püntener C, Billon-Bruyat J-P, Bocat L, Berger J-P, Joyce WG. 2014. Taxonomy and

766 phylogeny of the turtle Tropidemys langii Rütimeyer, 1873 based on new specimens from

767 the Kimmeridgian of the Swiss Jura Mountains. Journal of Vertebrate Paleontology 34:353-

768 374. DOI: $10.1080 / 02724634.2013 .804412$.

769 Riabinin ÀN. 1930. On the fauna and age of the dinosaur beds in Amur River. Zapiski

770 Rossiǔskogo mineralogicheskogo obshchestva 59(1):41-51.

771 Rieppel O. 1980. The skull of the Upper Jurassic cryptodire turtle Thalassemys, with a

772 reconsideration of the chelonian braincase. Palaeontographica, Abt. A 171:105-140.

773 Rütimeyer L. 1859a. Notiz über Schildkröten von Solothurn. Verhandlungen der

774 schweizerischen naturforschenden Gesellschaft 43:57-59.

775 Rütimeyer L. 1859b. Die Schildkröten im Portland-Kalk von Solothurn. Neues Jahrbuch für

776 Mineralogie, Geognosie, Geologie und Petrefakten-Kunde 1859:366.

777 Rütimeyer L. 1873. Die fossilen Schildkröten von Solothurn und der übrigen Juraformation.

778 Neue Denkschrift der allgemeinen schweizerischen naturforschenden Gesellschaft 25:1-185.

779 Schaefer K. 2012. Variabilité de la morphologie dentaire des crocodiliens marins

780 (Thalattosuchia) du Kimméridgien d'Ajoie (Jura, Suisse). Master Thesis, University of

$781 \quad$ Fribourg. 
782 Schaefer K, Billon-Bruyat J-P. 2014. The crocodilian Steneosaurus cf. bouchardi in the 783 Kimmeridgian of Switzerland [Abstract]. In: 12th Swiss Geoscience Meeting. Fribourg, 784 2014. 135-136.

785 Schweizerische Bundeskanzlei. 2015. Archiv "Das Wort des Monats". Available at

786 https://www.bk.admin.ch/themen/sprachen/00083/05668/index.html?lang=de (accessed 16 787 July 2015).

788 Seeley HG. 1869. Index to the fossil remains of Aves, Ornithosauria and Reptilia from the 789 Secondary System of strata arranged in the Woodwardian Museum of the University of $790 \quad$ Cambridge. Cambridge: Deighton, Bell, and Co.

791 Thurmann J, Etallon A. 1861-1864. Lethea Bruntrutana ou études paléontologiques et stratigraphiques sur les terrains jurassiques supérieurs du Jura bernois et en particulier des environs de Porrentruy. Denkschriften der allgemeinen Schweizerischen Gesellschaft für die gesamten Naturwissenschaften 18:1-145 (1861); 19:147-354 (1863); 20:355-500 (1864).

Young M, Hua S, Steel L, Foffa D, Brusatte SL, Thüring S, Mateus O, Ruiz-Omeñaca JI, Havlik P, Lepage Y, De Andrade MB. 2014. Revision of the Late Jurassic teleosaurid genus Machimosaurus (Crocodylomorpha, Thalattosuchia). Royal Society of open science 1:140222. DOI: $10.1098 /$ rsos. 140222 .

Zittel KA. 1889. Handbuch der Palaeontologie. Section 1: Palaeozoologie, Volume 3,

$800 \quad$ Vertebrata, Shipment 3: Reptilia. München: R. Oldenbourg. 
1

Geographical map of the Ajoie Region, Canton Jura, Switzerland.

The excavation sites Sur Combe Ronde (SCR) and Bois de Sylleux (BSY) are situated along the Transjurane A16 highway (gray; dotted lines indicate tunnels).

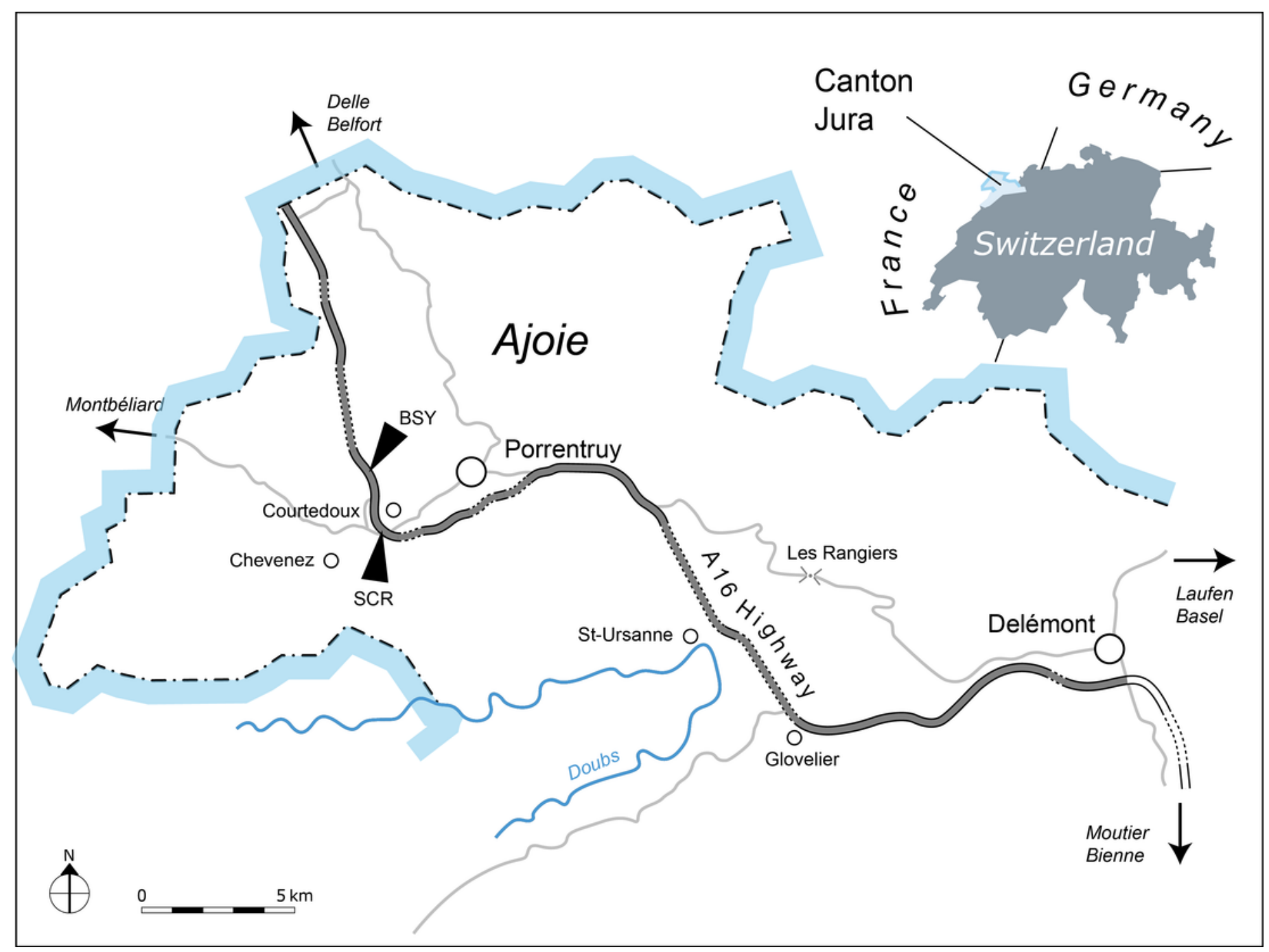


2

Stratigraphic section of the Reuchenette Formation.

The two Thalassemys specimens were discovered within the Lower Virgula Marls (Eudoxus ammonite zone). Scheme modified after Comment et al. (in press). 


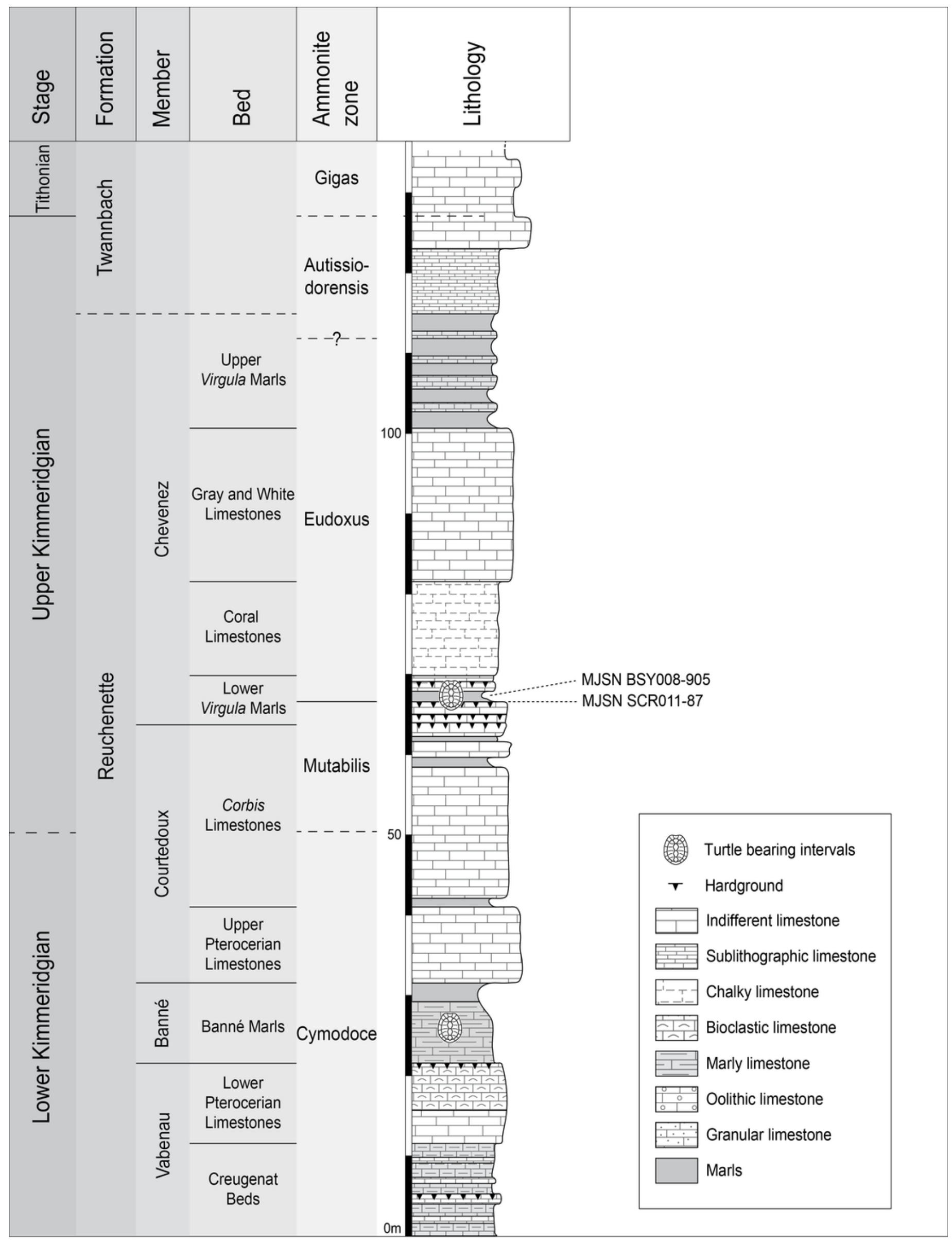




\section{3}

Carapaces of Thalassemys.

(A, B) Thalassemys bruntrutana, specimen MJSN SCR011-87 (Kimmeridgian, Porrentruy, Switzerland); (C, D) Thalassemys hugii, specimen NMS 8595-8609 (Kimmeridgian, Solothurn, Switzerland). Line width indicates natural borders (thick lines), bone sutures (medium lines), and fractures (thin lines); double lines indicate scale sulci; matrix is gray. Abbreviations: co, costal; n, neural; sp, suprapygal; v, vertebral scale, *, intermediate element (see text). 

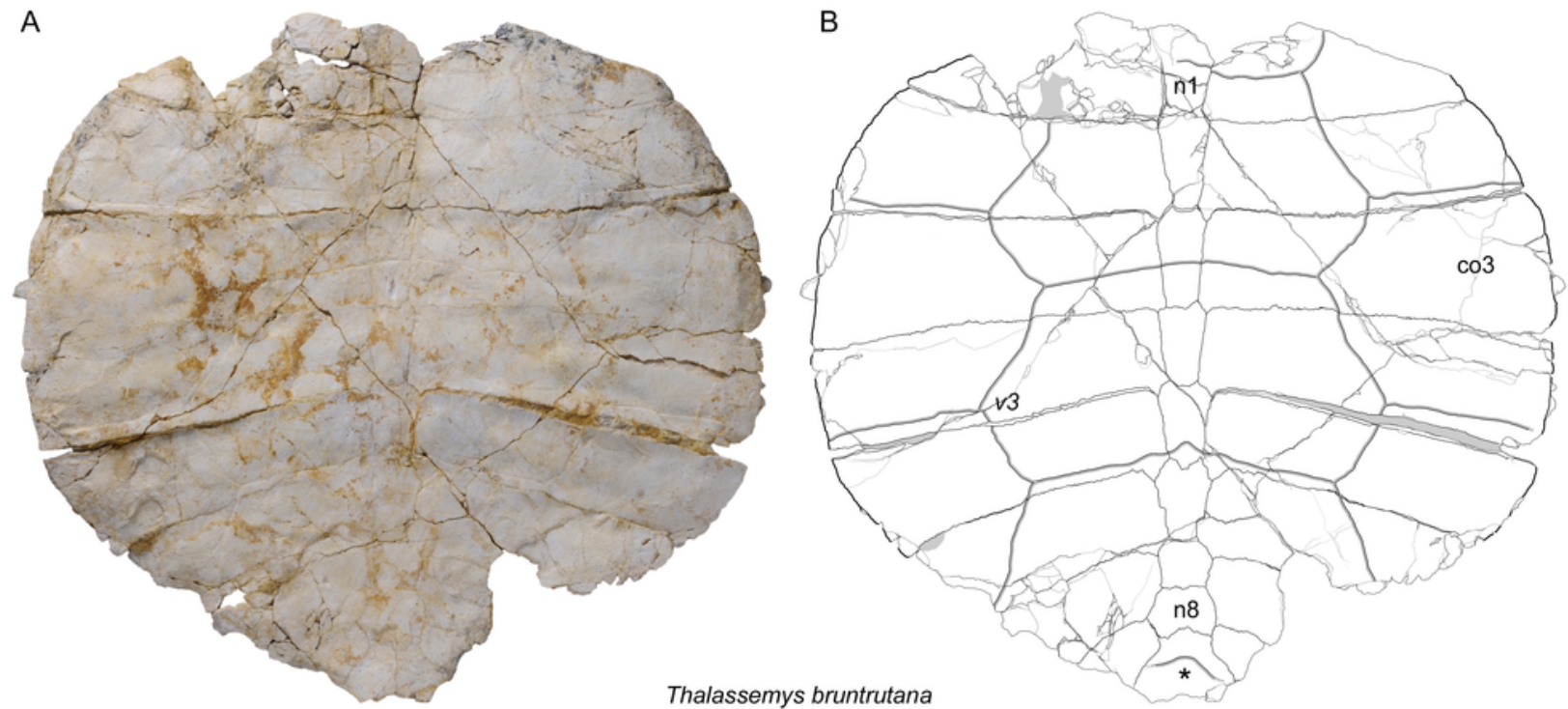

$100 \mathrm{~mm}$

C

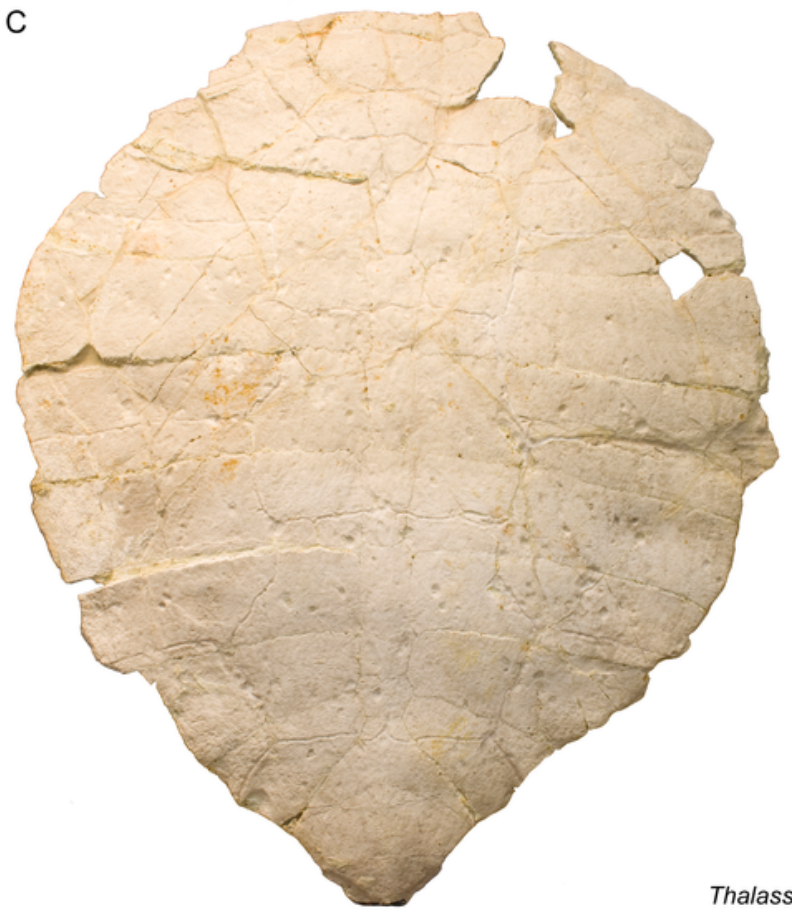

D

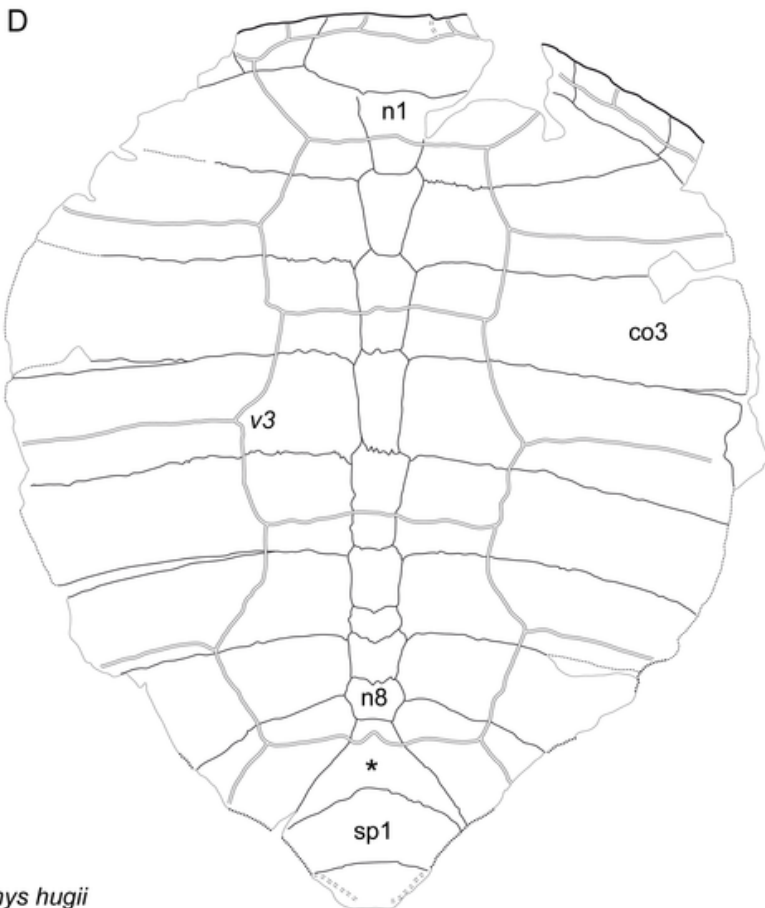


4

Nuchal of Thalassemys bruntrutana.

Specimen MJSN SCR011-87 (Kimmeridgian, Porrentruy, Switzerland). (A) dorsal view; (B) posterior view with the visceral side upward, showing the strong anterolateral thickening of the nuchal. 
PeerJ Reviewing Manuscript

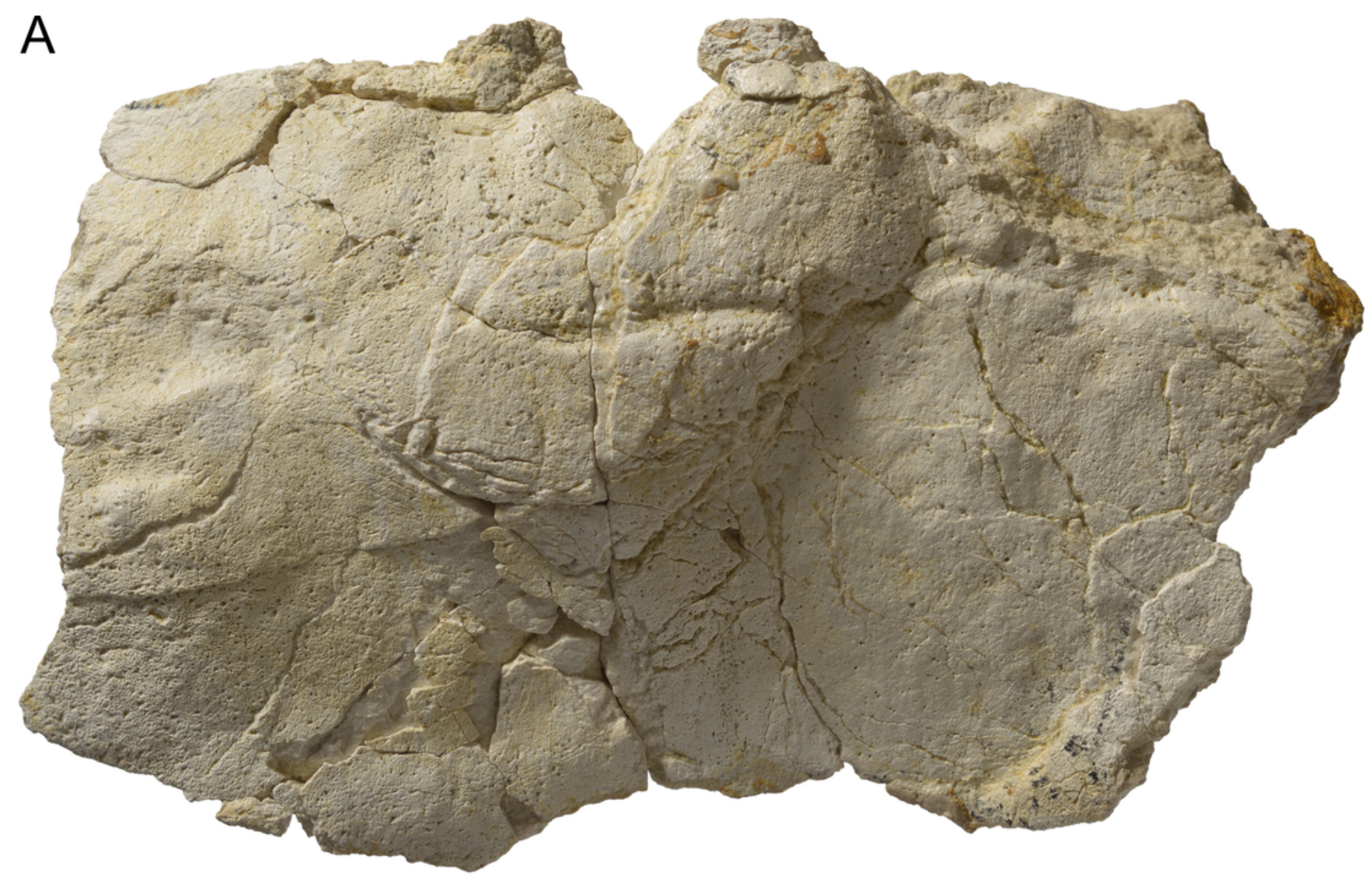

\section{$20 \mathrm{~mm}$}

\section{B}

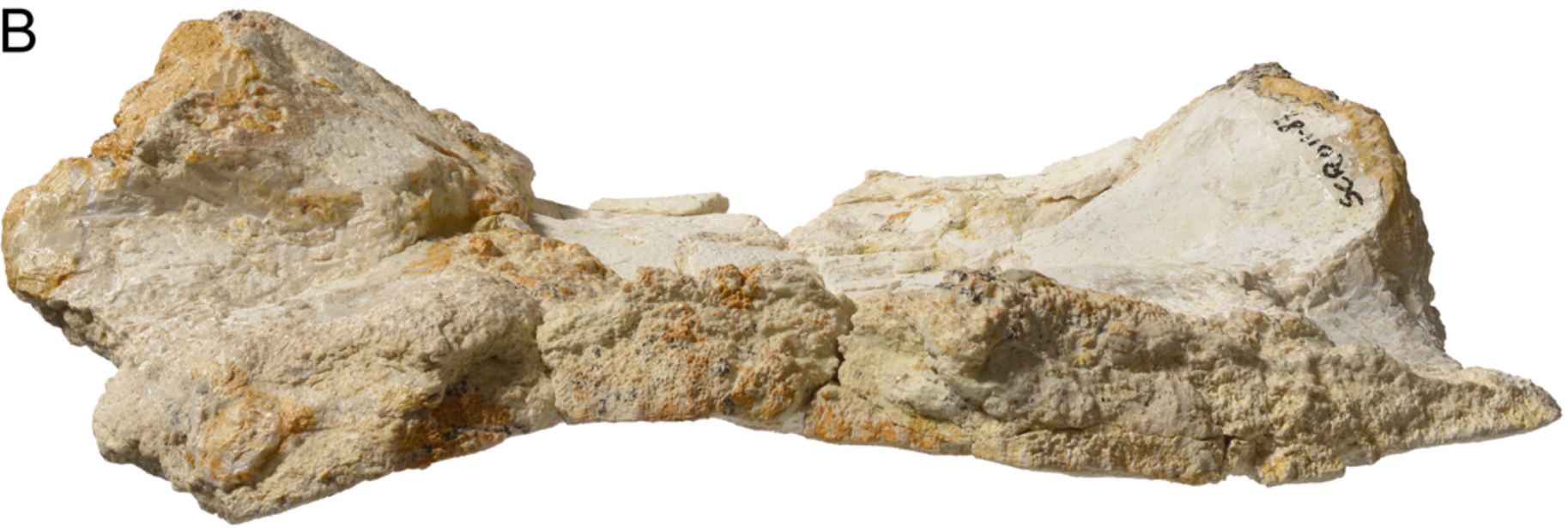




\section{5}

Peripherals of Thalassemys bruntrutana.

Specimen MJSN SCR011-87 (Kimmeridgian, Porrentruy, Switzerland). (A) group of peripherals in dorsal view; (B) two peripherals of the bridge area in ventral view; (C) peripheral of the bridge area in lateral view.

A

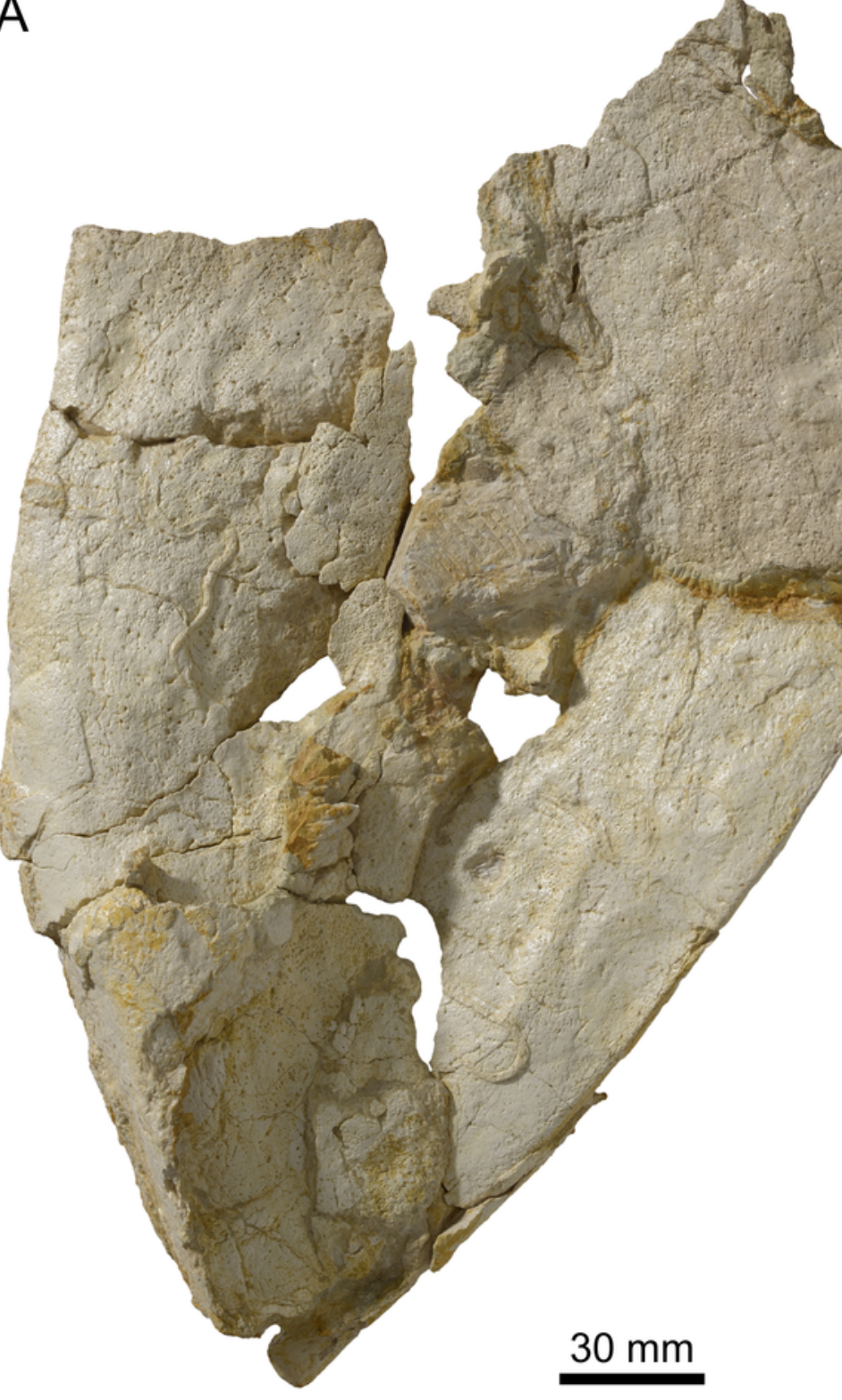

B

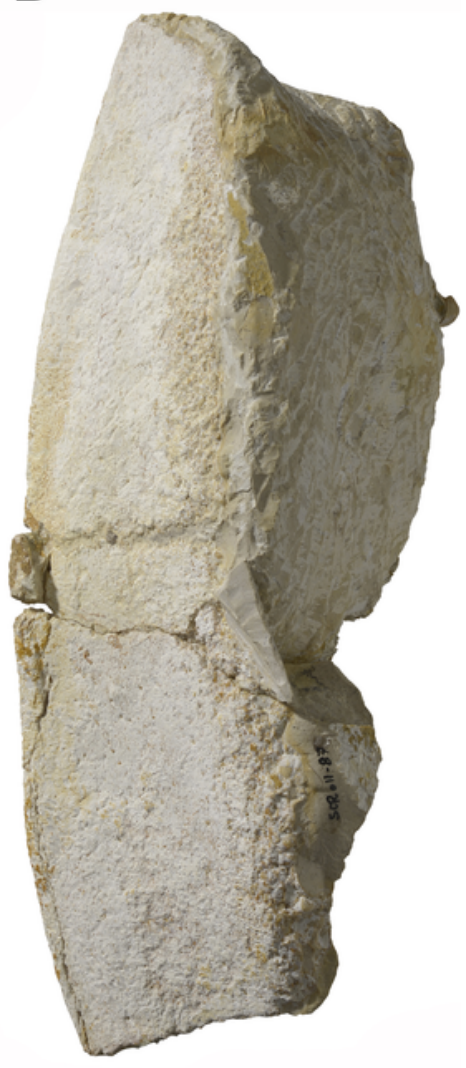

C

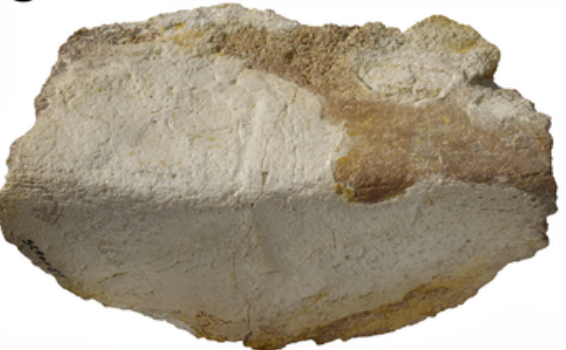


6

Plastra of Thalassemys.

(A, B) Thalassemys bruntrutana, specimen MJSN SCR011-87 (Kimmeridgian, Porrentruy, Switzerland); (C, D) Thalassemys hugii, specimen NMS 8595-8609 (Kimmeridgian, Solothurn, Switzerland). Line width indicates natural borders (thick lines), bone sutures (medium lines), and fractures (thin lines); double lines indicate scale sulci. Abbreviations: cpf, central plastral fontanelle; Ipf, lateral plastral fontanelle; hyo, hyoplastron; hypo, hypoplastron; xi, xiphiplastron. 
A

A

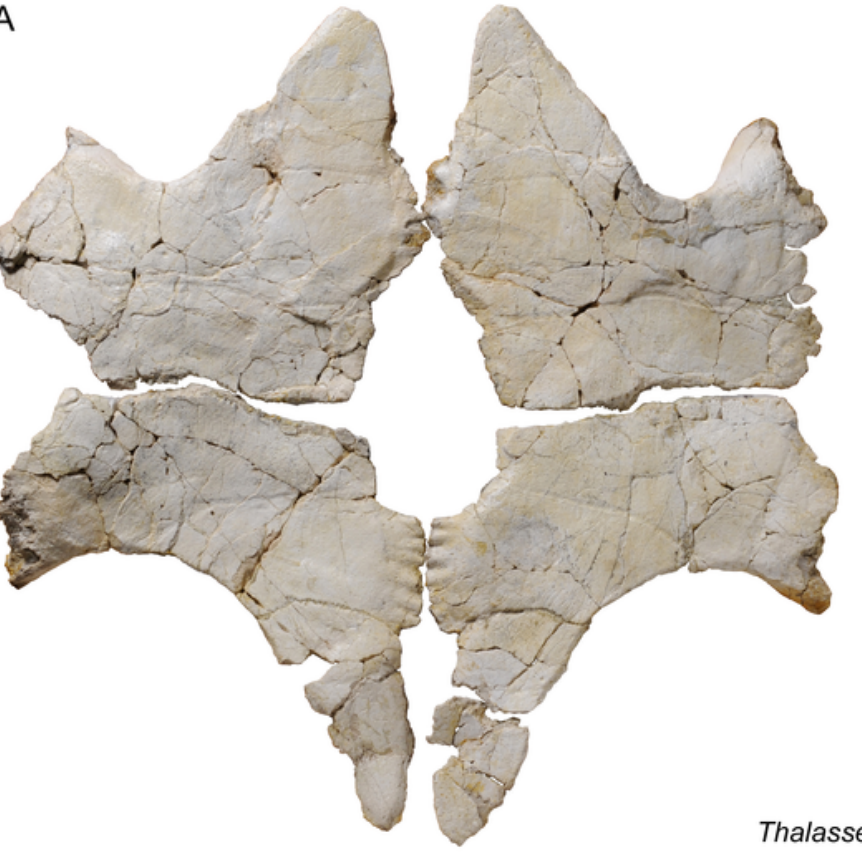

Thalassemys bruntrutana

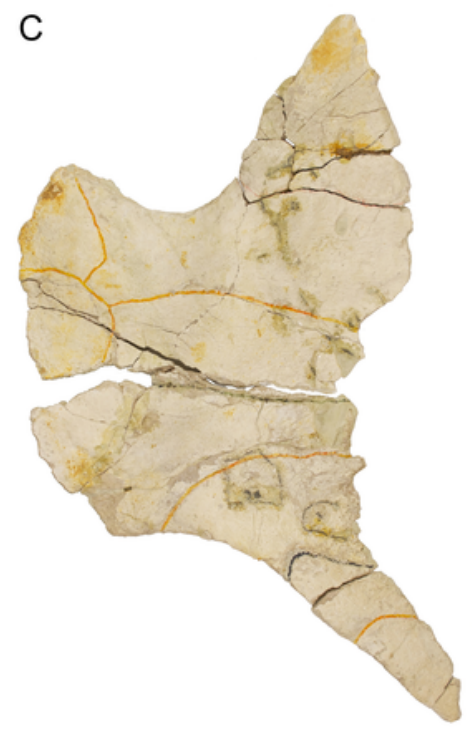

Thalassemys hugii
B

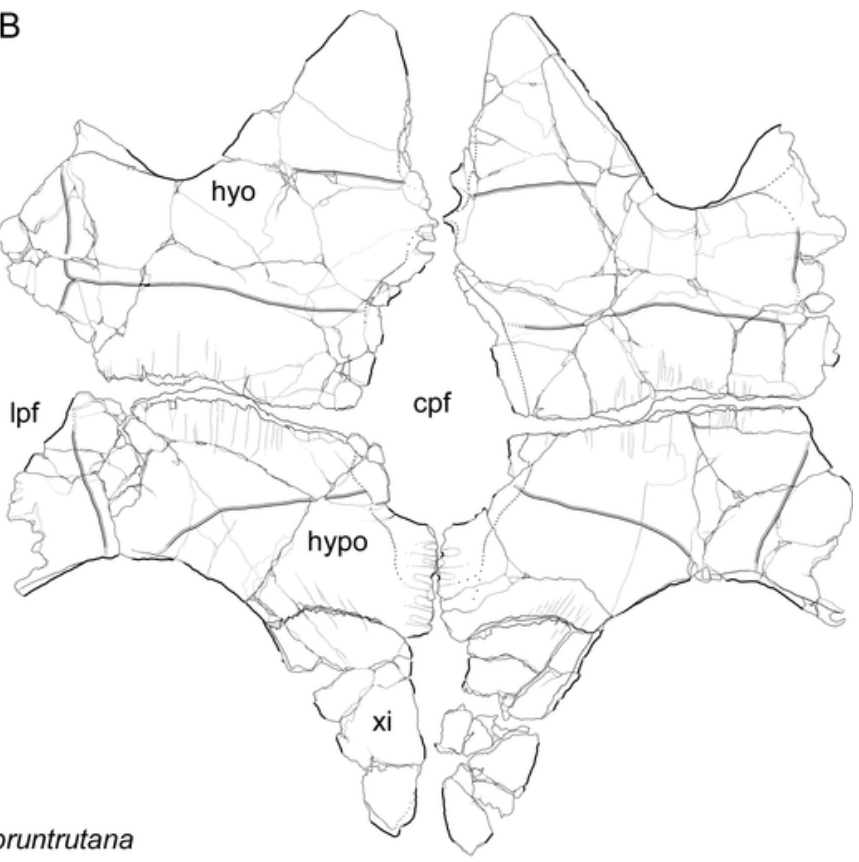

D
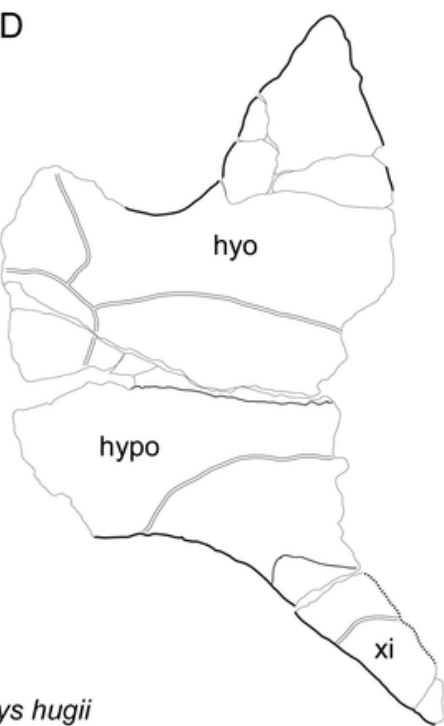

$100 \mathrm{~mm}$ 


\section{7}

Scapulae of Thalassemys.

Lateral (A) and medial (B) view of the left scapula of Thalassemys bruntrutana, specimen MJSN SCR011-87 (Kimmeridgian, Porrentruy, Switzerland); Lateral (C) and medial (D) view of the left scapula of Thalassemys hugii, specimen NMS 8595-8609 (Kimmeridgian, Solothurn, Switzerland). 
A

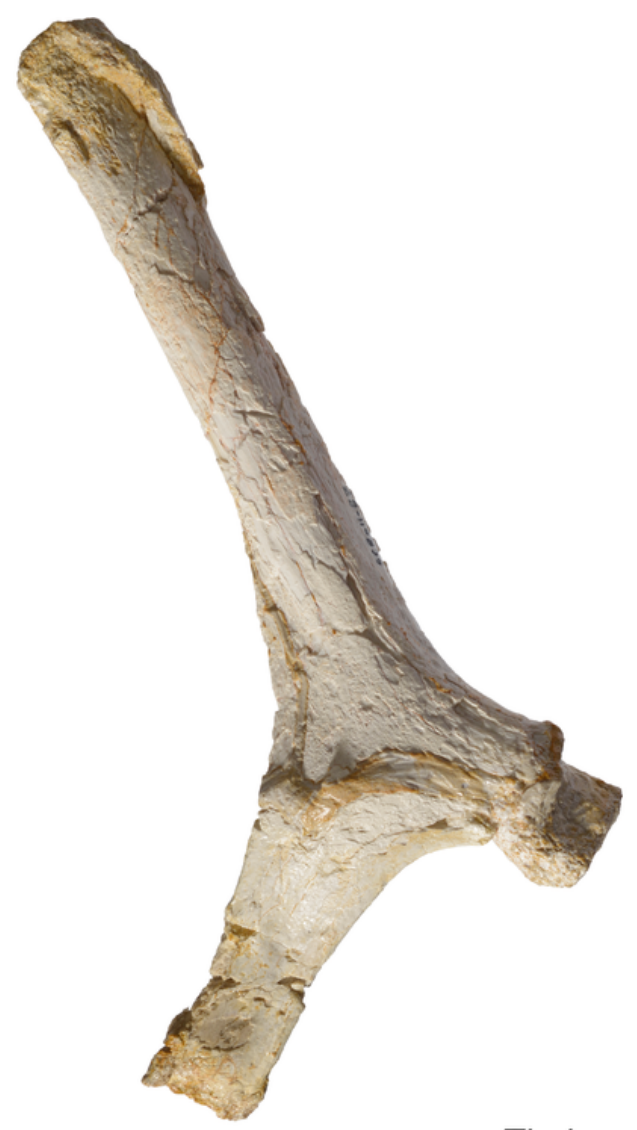

Thalassemys bruntrutana

C

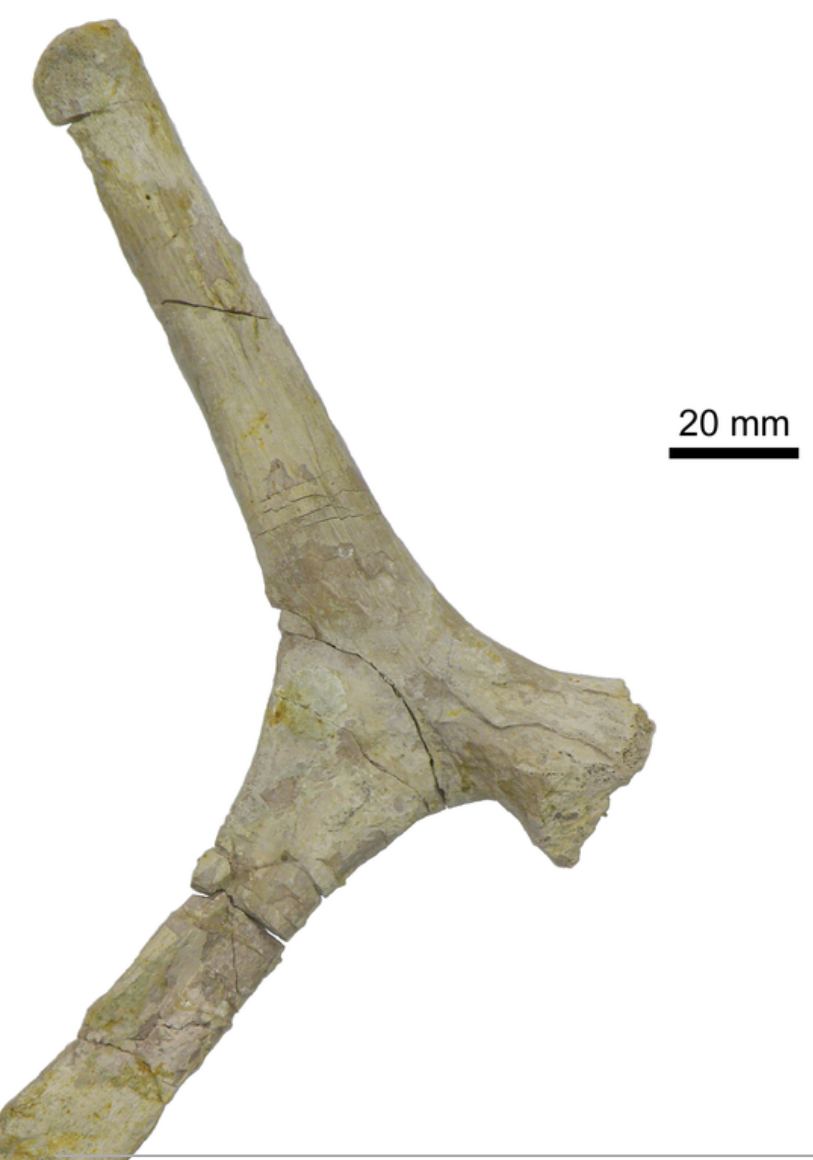

Peerf reviewing PDF | (2015:07:5942:2:0:NEW 8 Sep 2015)
B

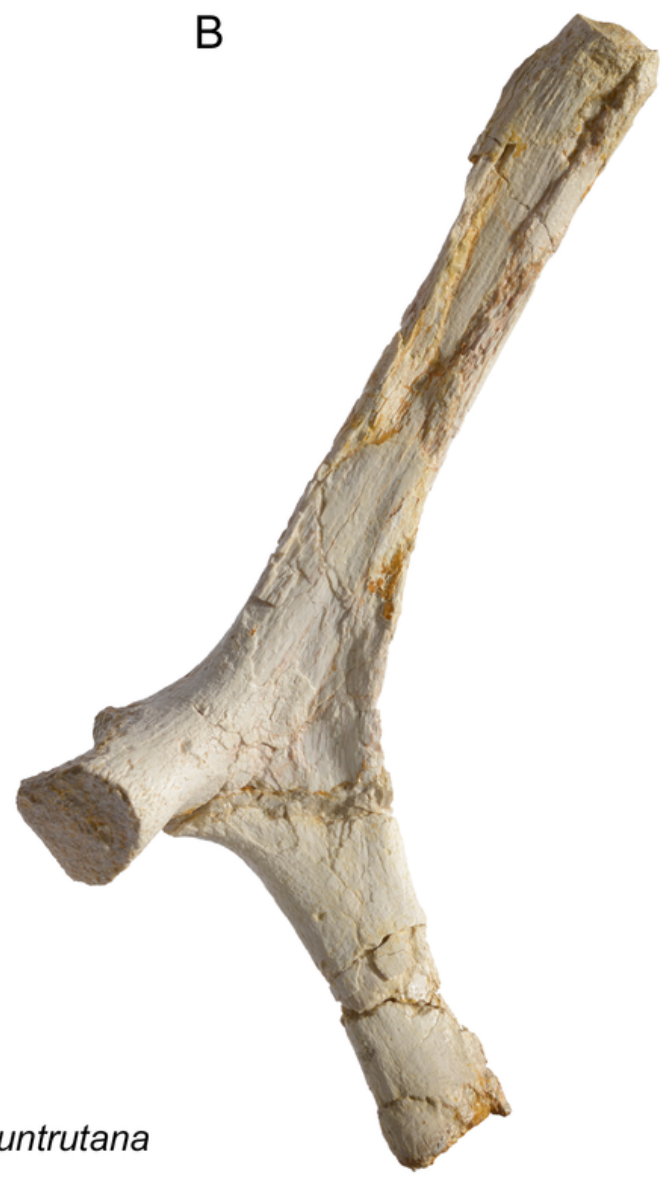

D

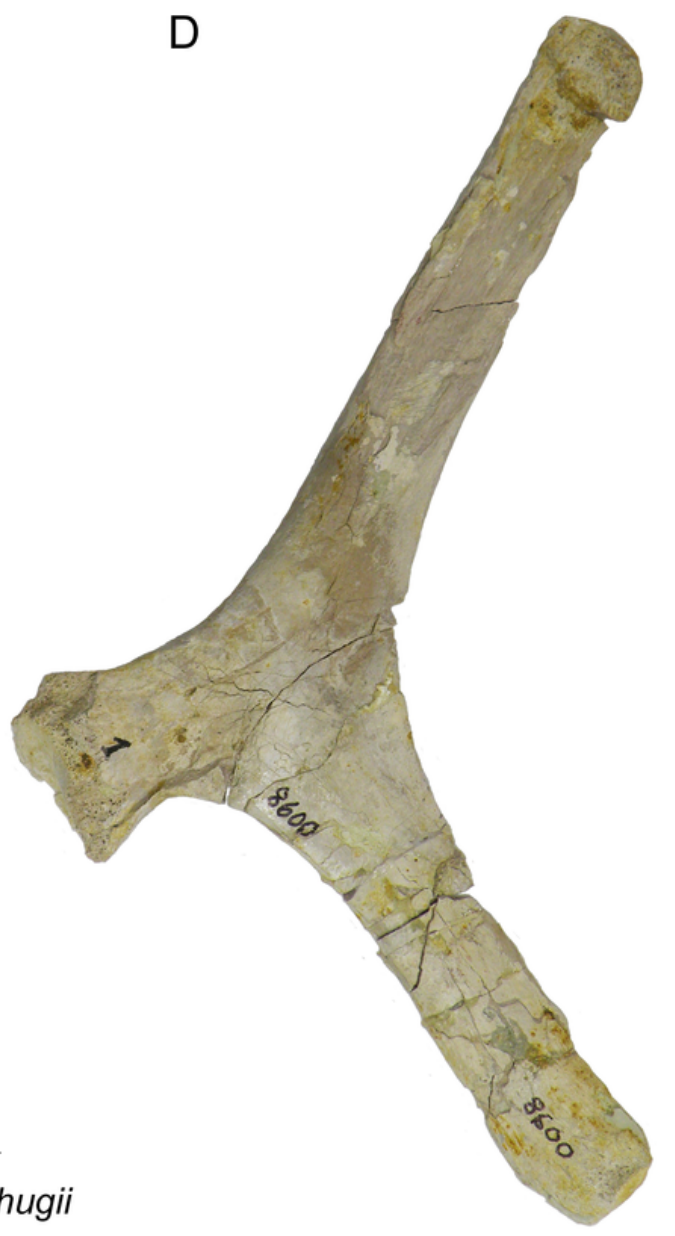


8

MJSN BSY008-905, Thalassemys hugii (Kimmeridgian, Porrentruy, Switzerland).

(A, B) carapace; (C, D) plastron; lateral (E) and medial (F) view of the (left?) scapula. Line width indicates natural borders (thick lines), bone sutures (medium lines), and fractures (thin lines); double lines indicate scale sulci. Abbreviations: co, costal; n, neural; nu, nuchal; v, vertebral scale; hyo, hyoplastron; hypo, hypoplastron; xi, xiphiplastron. 
A
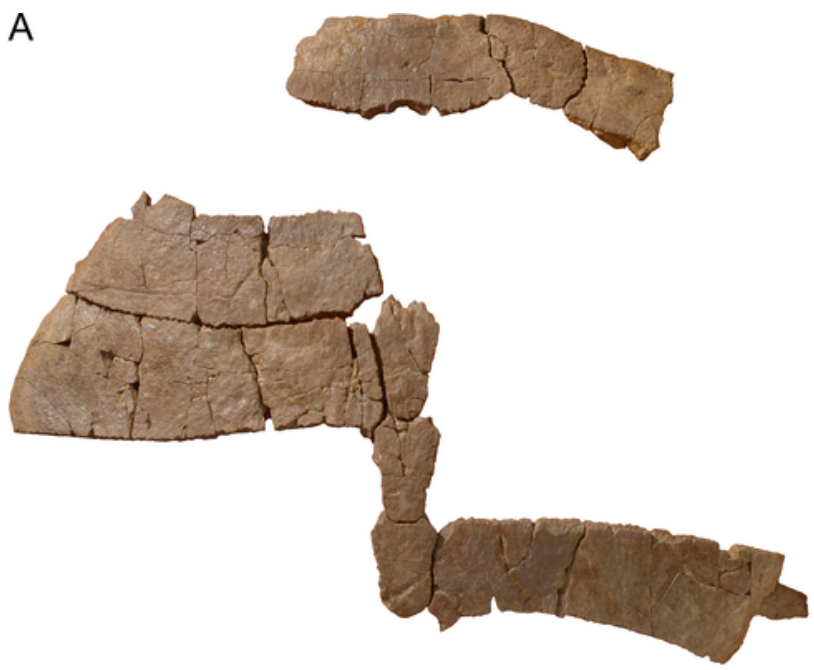

C

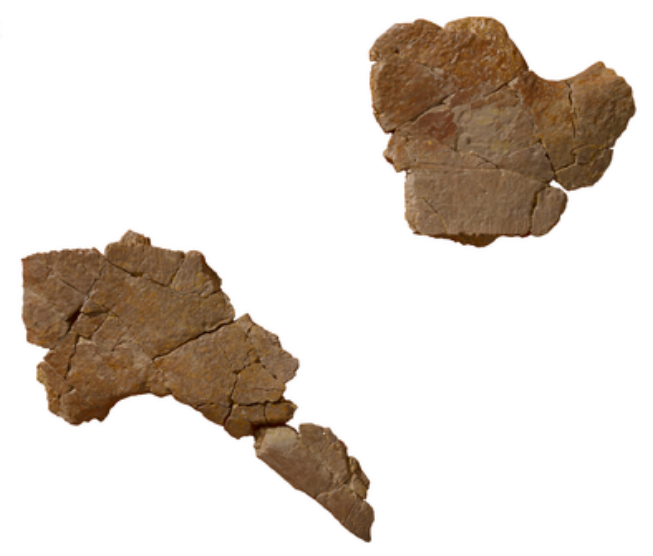

E

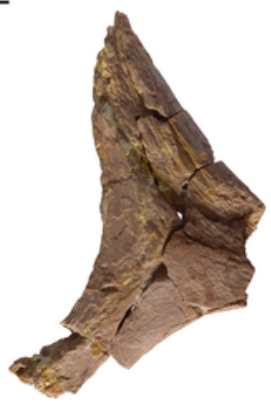

B
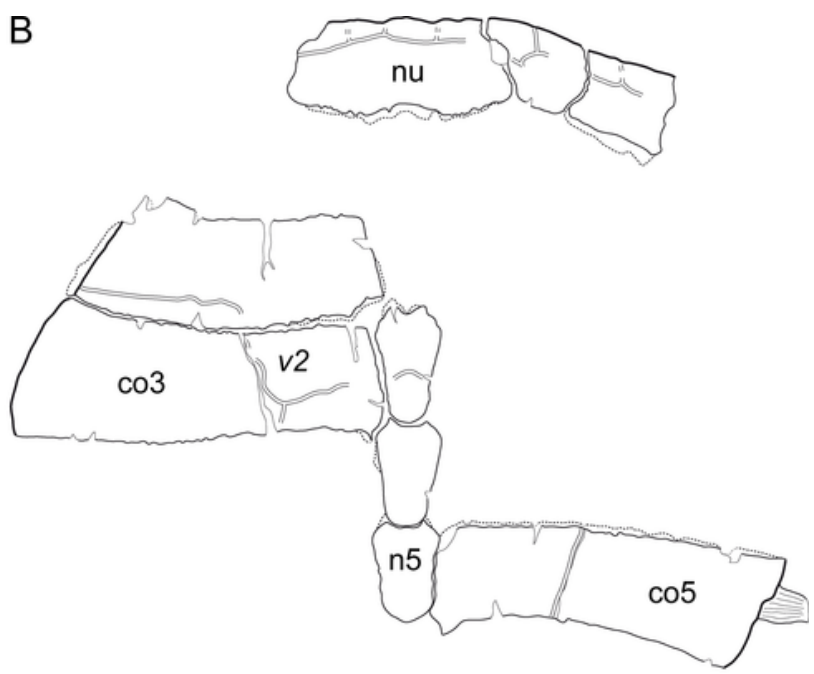

$100 \mathrm{~mm}$

D

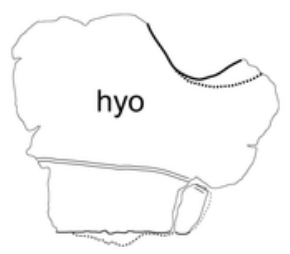

$20 \mathrm{~mm}$

$\mathrm{F}$

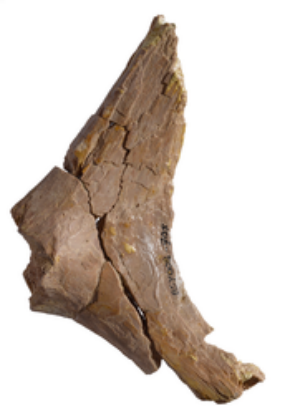


9

Paleobiogeographic distribution of Thalassemys.

Localities with Thalassemys species from the Kimmeridgian (black stars) and Tithonian (white star) on a Late Jurassic paleogeographic map of Western Europe. Map from Ron Blakey, Colorado Plateau Geosystems, Arizona, USA (http://cpgeosystems.com/paleomaps.html).

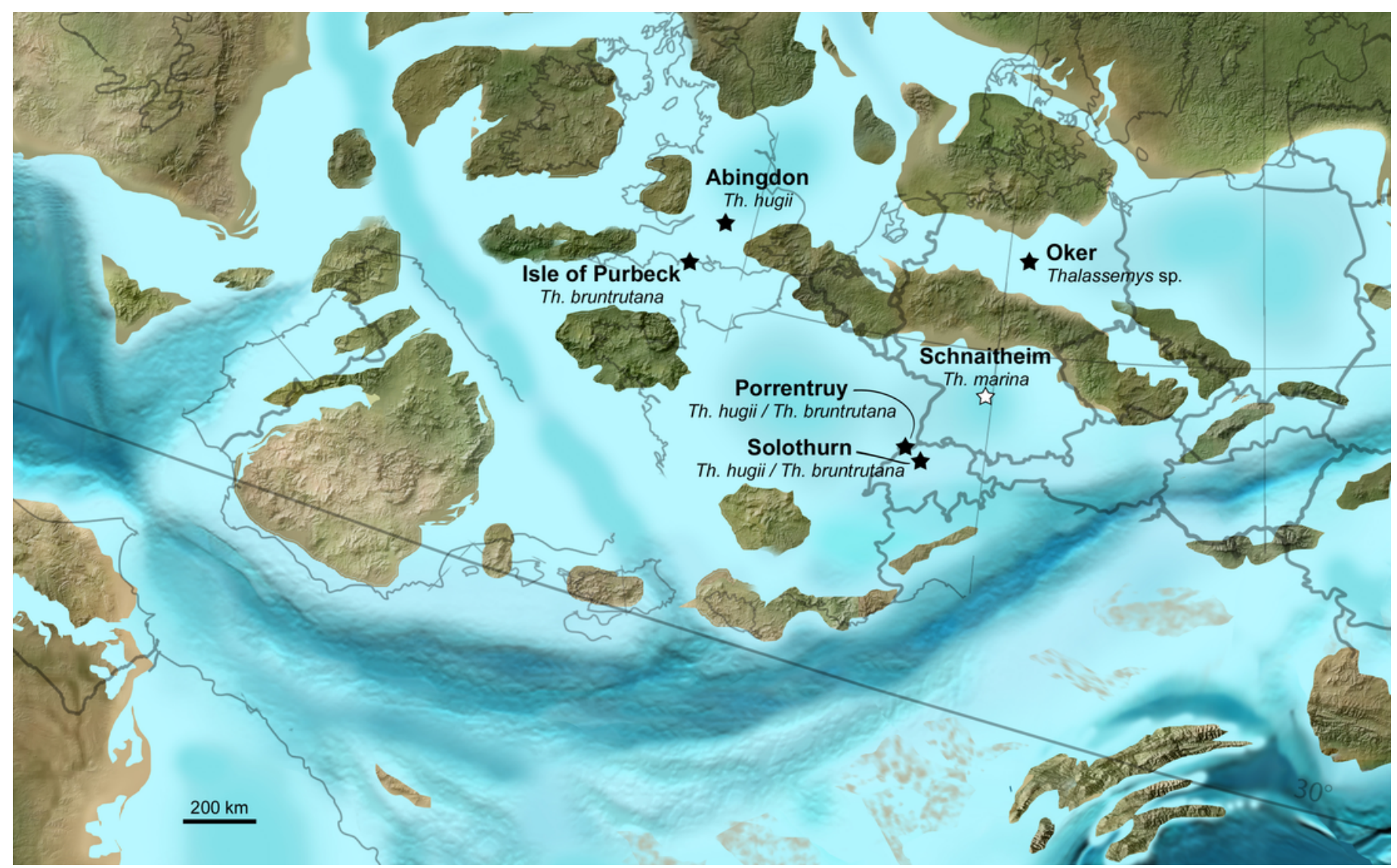


Table $\mathbf{1}_{\text {(on next page) }}$

The angle between scapular process and acromion process in specimens of Thalassemys and Plesiochelys.

When the two scapulae were preserved, both were measured. The high value for the right

scapula of NMS 8631-8643 must therefore be treated with caution with regard to taphonomic compaction. 


\begin{tabular}{|l|l|c|}
\hline Specimen & Species & Scapular angle \\
\hline NMS 8595-8609 & Th. hugii & $118^{\circ}$ \\
\hline NMS 8612-8627 & Th. hugii & $114^{\circ} / 113^{\circ}$ \\
\hline NMS 8631-8643 & Th. hugii & $113^{\circ} / 122^{\circ}$ \\
\hline MJSN BSY008-905 & Th. hugii & $116^{\circ}$ \\
\hline MJSN SCR011-87 & Th. bruntrutana & $130^{\circ}$ \\
\hline NHMUK R8699 & Th. bruntrutana ${ }^{\text {a }}$ & $103^{\circ}$ \\
\hline NMS 8584 & P. etalloni & $103^{\circ}$ \\
\hline NMS 8731 & P. etalloni & $103^{\circ}$ \\
\hline NMS 9153 & P. etalloni & $105^{\circ}$ \\
\hline
\end{tabular}

1

2 a Thalassemys sp. in Pérez-García (2015). 
Table 2 (on next page)

The angle between the anteroposterior axis of the plastron and the lateral border of the xiphiplastron in specimens of Thalassemys. 


\begin{tabular}{|l|l|c|}
\hline Specimen & Species & Xiphiplastral angle \\
\hline NMS 8595-8609 & Th. hugii & $45^{\circ}$ \\
\hline MJSN BSY008-905 & Th. hugii & $49^{\circ}$ \\
\hline OUMNH J.66966 & Th. hugii & $48^{\circ}$ \\
\hline NMS 9144 & ${\text { Th. } \text { bruntrutana }^{\text {b }}}^{\circ}$ & $30^{\circ}$ \\
\hline NMS 37251 & ${\text { Th. } \text { bruntrutana }^{\text {b }}}^{\circ}$ & $29^{\circ}$ \\
\hline MJSN SCR011-87 & Th. bruntrutana $^{\circ}$ & $30^{\circ}$ \\
\hline
\end{tabular}

1

2 a cf. Pérez-García (in press).

3 b Thalassemys hugii in Anquetin, Püntener \& Billon-Bruyat (2014).

4 